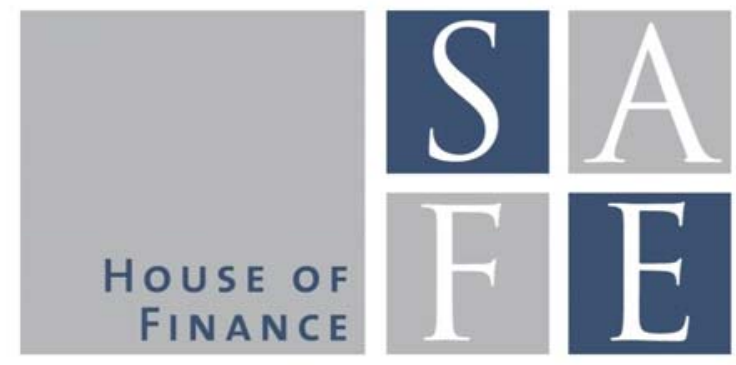

WORKING PAPER SERIES

Giuliano Curatola - Michael Donadelli - Patrick Grüning - Christoph Meinerding

\title{
Investment-Specific Shocks, Business Cycles, and Asset Prices
}

SAFE Working Paper No. 129

SAFE I Sustainable Architecture for Finance in Europe A cooperation of the Center for Financial Studies and Goethe University Frankfurt 


\section{Non-Technical Summary}

Recent studies show that investment-specific shocks (e.g. shocks to the marginal efficiency of investment, or shocks to the capital depreciation rate) are a key driver of macroeconomic fluctuations. Additionally, it has been shown that these shocks help in bringing asset prices and macroeconomic quantities closer to their empirical counterparts.

However, there are still some open questions concerning the role of investment-specific shocks for the dynamics of macroeconomic and financial variables. On the one hand, economic models relying exclusively on investment shocks tend to produce a negative correlation between consumption and investment, contrary to what data suggest. On the other hand, studies examining the role of both aggregate productivity and investment-specific shocks show that the former does not match first and second moments of asset prices if a quantitatively relevant investment-specific shock is missing.

In this paper, we develop a two-sector (consumption and investment) production economy where the combination of long-run productivity risk in both sectors and wage rigidities helps in resolving the aforementioned issues. In this respect, our paper contributes to the existing literature by examining the joint effect of investment-specific shocks on both asset prices and macroeconomic quantities.

After providing an empirical justification for the presence of a long-run risk component in both sectors, we show that long-run investment-specific shocks act as a substitute for a stochastic marginal efficiency of investment. In particular, even in the absence of a shock to the marginal efficiency of investment, our economy gives rise to a sizeable aggregate risk premium and a low and smooth risk-free rate, and it reproduces the empirically observed spread in the stock return volatilities of the two sectors. Once a moderate amount of wage rigidities is added, the model is also capable of reproducing the empirically observed positive co-movement between consumption and investment growth. 


\title{
Investment-Specific Shocks, Business Cycles, and Asset Prices
}

\author{
Giuliano Curatola* Michael Donadelli* Patrick Grüning** Christoph Meinerding*
}

This version: March 14, 2016

\begin{abstract}
We introduce long-run investment productivity risk in a two-sector production economy to explain the joint behavior of macroeconomic quantities and asset prices. Long-run productivity risk in both sectors, for which we provide economic and empirical justification, acts as a substitute for shocks to the marginal efficiency of investments in explaining the equity premium and the stock return volatility differential between the consumption and the investment sector. Moreover, adding moderate wage rigidities allows the model to reproduce the empirically observed positive co-movement between consumption and investment growth.
\end{abstract}

Keywords: General Equilibrium Asset Pricing, Production Economy, Long-Run Risk, Investment-Specific Shocks, Nominal Rigidities

JEL: E32, G12

\footnotetext{
${ }^{*}$ Faculty of Economics and Business Administration and Research Center SAFE, Goethe University Frankfurt. Emails: curatola@safe.uni-frankfurt.de,donadelli@safe.uni-frankfurt.de, meinerding@finance.uni-frankfurt.de.

${ }^{* *}$ Center for Excellence in Finance and Economic Research (CEFER), Bank of Lithuania, and Faculty of Economics, Vilnius University. E-mail: PGruening@lb.lt.

We thank Roberto Pancrazi, Christian Schlag, Ctirad Slavík, as well as participants at the 11th Dynare Conference and the BICEPS/SSE Riga research seminar for helpful comments and criticism. We gratefully acknowledge research and financial support from the Research Center SAFE, funded by the State of Hessen initiative for research LOEWE. The views expressed herein are solely those of the authors and do not necessarily reflect the views of the Bank of Lithuania or the Eurosystem.
} 


\section{Introduction}

Investment-specific shocks have been shown to be an important driver of the dynamics of asset prices and macroeconomic quantities in general equilibrium models. Papanikolaou (2011) argues that investment shocks can simultaneously reproduce the value premium, first and second moments of stock returns, as well as the co-movement of some key macroeconomic quantities. Justiniano et al. $(2010,2011)$ find that investment shocks are the main driver of business cycle fluctuations in the US economy. However, conventional models that attribute a central role to investment shocks tend to produce a negative correlation between consumption and investment, contrary to the empirical evidence. ${ }^{1}$ Moreover, in the model of Papanikolaou (2011) shocks to the total factor productivity (TFP) of the investment sector encounter difficulties in explaining the basic unconditional moments of equity returns unless an additional source of uncertainty is added to the model, in this case shocks to the marginal efficiency of investments. ${ }^{2}$

In this paper, we show that a new, previously disregarded channel, namely long-run shocks to the productivity of the investment sector, can resolve these issues. To arrive at this result, we proceed in two steps. First, we propose a dynamic stochastic general equilibrium (DSGE) model with two sectors (consumption and investment sector), whose TFP processes are both driven by short- and long-run components. In a second step, we add some very moderate frictions, in particular capital adjustment costs in the spirit of Jermann (1998) and wage rigidities as suggested by Uhlig (2007). Our paper thus adds to the, up until now and to the best of our knowledge, very thin literature about the joint effect of investment shocks on both asset prices and macroeconomic quantities.

Theoretically, the presence of a long-run component in the productivity of investments can be justified by the idea of investment hysteresis originally proposed by Dixit (1992). The traditional theory of investment postulates that firms should invest (or enter the market) when the price exceeds the average variable costs and disinvest (or exit the market) when the price falls below the average variable costs. However, empirical evidence indicates that, once firms have invested in a project, they tend to stay in business and continue their investment even when the underlying causes of investment are fully reversed. This suggests that investment drivers may have long-lasting effects. ${ }^{3}$ Our assumption of long-run investment specific shocks is also motivated by the empirical evidence of Greenwood et al. (2000) and Croce (2014). We estimate the TFP processes using sectoral output data and confirm the presence of a long-run risk component in the TFP processes of both the consumption and the investment sector.

\footnotetext{
${ }^{1}$ This co-movement problem is well documented by Khan and Tsoukalas (2011), Furlanetto et al. (2013) and Furlanetto and Seneca $(2014 a, b)$.

${ }^{2}$ More precisely Papanikolaou (2011) shows that, in order to match the equity premium and volatility of stock returns, one would need an unrealistically high volatility of investment TFP shocks when the marginal efficiency of investment is deterministic.

${ }^{3}$ The empirical evidence on investment hysteresis is still fragmented. A review of sectoral and experimental evidence on this topic can be found in Kogut and Chang (1996), Barham et al. (1998), Bragger et al. (2003), Richard and Green (2003), Hinrichs et al. (2008) and Musshoff et al. (2013). A deep economic motivation for a delayed exit strategy is provided by Bernanke (1983). Further theoretical studies that point to the importance of long-term trends in investment dynamics are provided by Dixit (1989), Bar-Ilan and Strange (1996), Bar-Ilan and Strange (1999), and Kogan (2001).
} 
The presence of long-run risk in the consumption sector, together with capital adjustment costs, allows the model to generate a sizable equity premium and a low and stable risk-free rate. Introducing long-run risk in the investment sector then helps to reproduce the empirically observed spread in the stock return volatilities of the two sectors. Both results can be obtained without assuming a stochastic marginal efficiency of investment. In a robustness check, we show that, in fact, long-run investmentspecific shocks act as a substitute for a stochastic marginal efficiency of investment. This is an important contribution of our paper for two reasons. First, as opposed to the parameters of the marginal efficiency of investment, the parameters of the long-run TFP component can be estimated by employing existing standard techniques (see Croce (2014), Edge et al. (2007)). Second, the two approaches offer different explanations for the economic link between the risk of the investment sector and asset prices. Shocks to the marginal efficiency of investments affect output and asset prices "only to the extent that they are implemented through the formation of new capital stock" (Papanikolaou (2011)). Differently, investment TFP shocks alter the perception regarding long-term productivity, and this effect, which goes above and beyond the effect of investment shocks for the cost of producing new capital, is important for explaining the risk-return differential between the consumption and the investment sector. Given also the empirical evidence, we thus think that long-run investment shocks are a very natural modeling choice. Moreover, long-run risk in the consumption and in the investment sector allows us to obtain the asset pricing results with relatively moderate capital adjustment costs.

However, long-run investment risk alone does not resolve the macroeconomic co-movement problem in the sense that the correlation between consumption and investment remains negative. More precisely, short-run investment shocks tend to produce negative co-movement between consumption and investment, while long-run investment shocks result in a positive co-movement. The former effect dominates the latter, resulting in an overall negative co-movement between consumption and investment. Nevertheless, the trade-off between these two effects can be controlled by varying the amount of wage rigidities. In particular, we show that moderate wage rigidities are sufficient to reproduce the observed positive correlation between consumption and investment. Wage rigidities have already been used in the asset pricing literature. For example, Uhlig (2007) shows that a DSGE model with external habits and wage rigidities explains the main properties of asset prices. Favilukis and Lin (2016) show that wage rigidities explain not only the dynamics of aggregate asset prices, but also the value premium and the downward-sloping term structure of equity. Petrosky-Nadeau et al. (2015) find that wage rigidities, to- 
gether with search frictions in the labor market, endogenously create rare disasters in the spirit of Barro (2006). Our analysis demonstrates that wage rigidities, together with our newly proposed channel of long-run investment-specific shocks, improve the ability of DSGE models to match the joint behavior of (cross-sectional) asset prices and macroeconomic quantities.

Because we focus on both asset prices and macroeconomic quantities, our results contribute to the recent literature that tries to improve the empirical predictions of general equilibrium models with investment shocks. Khan and Tsoukalas (2011) suggest that the co-movement problem can be solved when the cost of capital utilization is specified in terms of increased capital depreciation instead of foregone consumption. Furlanetto and Seneca (2014a) argue that a positive co-movement between consumption and investment obtains in models with price rigidities. Finally, Furlanetto et al. (2013) propose an explanation for the co-movement problem that relies on rule-of-thumb households who do not smooth consumption through financial markets, but spend their entire income in each period to finance consumption. Sudo (2012) accounts for the co-movement problem by requiring investment good producing firms to use final consumption goods as input in their production functions. However, all these papers remain silent about the implications for financial markets and thus for asset pricing moments.

On the other hand, the recent asset pricing literature about investment shocks has difficulties in matching key macroeconomic quantities. For instance, Papanikolaou (2011) manages to match the correlations between consumption, investment, and output growth, but only with a stochastic marginal efficiency of investment, which is hard to justify empirically. Moreover does his model not match the correlation between consumption and hours worked. Kogan and Papanikolaou (2014) show that investment shocks have explanatory power for the cross-section of stock returns, but do not add further insights about the implications for macroeconomic co-movements. The model of Garlappi and Song (2013) features a continuum of consumption goods and a variable capital depreciation rate, and the authors show that the market price of risk for investment shocks depends on the competitiveness and the flexibility of the utilization rate of capital. Kogan et al. (2015) explain the value-growth return differential with a model in which the gains from innovation are distributed asymmetrically among the agents. They do not explicitly refer to long-run investment-specific shocks, but their main mechanism relies on the existence of technological progress which is embodied in new vintages of capital permanently.

Taken together, our main contribution lies in analyzing the joint effect of long-run productivity risk in both sectors in conjunction with nominal rigidities on both asset prices and macroeconomic quantities. 
After all, investment shocks have been advocated not only as an important driver of the business cycle but also as a driver of expected stock returns and return volatilities. Therefore a consistent explanation of macroeconomic co-movements that relies on investment shocks should also be able to provide a reasonable fit for the key moments of asset prices, and vice versa. Our results suggest that long-run investmentspecific shocks contribute a great deal to explaining the dynamics of asset prices, but need to be coupled with nominal rigidities (or other sources of market imperfections) to generate realistic macroeconomic co-movements.

The remainder of this paper is structured as follows. Section 2 describes the economy. The calibration of the model is dicussed in Section 3. In Section 4 we analyze the quantitative implications of our model. Section 5 concludes.

\section{Model}

In the following subsections, we develop a dynamic stochastic general equilibrium (DSGE) model with two sectors that allows us to study the asset pricing implications of various shocks to investment good productivity and efficiency. The first sector is the consumption good sector. It admits a fairly standard competitive representative firm that uses capital and labor to produce consumption goods which it supplies to the representative household for consumption. The second sector is the investment good sector. It uses labor to produce investment goods which it sells to the consumption good sector at a monopolistic price. The representative household owns both sectors, has recursive preferences over consumption and leisure and freely allocates labor to the two sectors. The production technologies in both sectors are subject to both short- and long-run productivity shocks. In a robustness check, the marginal efficiency of investment is allowed to be stochastic. A summary of the equilibrium conditions and details about the solution of the model are provided in Appendix A. 


\section{$2.1 \quad$ Representative household}

Because we want to focus on the trade-off between short-run and long-run shocks, we assume that the representative agent has recursive preferences as in Epstein and Zin (1989) over the utility flow $v_{t}$

$$
U_{t}=\left[(1-\beta) v_{t}^{1-\frac{1}{\psi}}+\beta\left(\mathbb{E}_{t}\left[U_{t+1}^{1-\gamma}\right]\right)^{\frac{1-1 / \psi}{1-\gamma}}\right]^{\frac{1}{1-1 / \psi}}
$$

where $\gamma$ denotes the relative risk aversion (RRA), $\psi$ measures the elasticity of intertemporal substitution (EIS), and $\beta \in(0,1)$ is the household's subjective discount factor. Note that this preference specification allows to separate the relative risk aversion from the elasticity of intertemporal substitution. The utility flow, $v_{t}$, is a Cobb-Douglas index of aggregate consumption $C_{t}$ and leisure $1-L_{t}$

$$
v_{t}:=v\left(C_{t}, L_{t}\right)=C_{t}^{\nu}\left(A_{C, t}\left(1-L_{t}\right)\right)^{1-\nu},
$$

where $\nu \in(0,1)$ reflects preferences for consumption versus leisure. $A_{C, t}$ (to be defined later) is is the productivity of the consumption good sector and can be interpreted as the households' standard of living in the spirit of Croce (2014). ${ }^{4}$

In each period, the representative household chooses consumption $C_{t}$ and labor $L_{t}$ to maximize (1) subject to the following budget constraint

$$
C_{t}+B_{t+1}+\vartheta_{C, t+1}\left(V_{C, t}-D_{C, t}\right)+\vartheta_{I, t+1}\left(V_{I, t}-D_{I, t}\right)=W_{t}^{u} L_{t}+B_{t} R_{t}^{f}+\vartheta_{C, t} V_{C, t}+\vartheta_{I, t} V_{I, t}
$$

where $\vartheta_{C, t}\left(\vartheta_{I, t}\right)$ denotes equity shares in the representative consumption (investment) good sector firm held from time $t-1$ to time $t, V_{C, t}\left(V_{I, t}\right)$ is the cum-dividend market value of the consumption (investment) good sector, $D_{C, t}\left(D_{I, t}\right)$ represents the consumption (investment) good sector's dividends, $B_{t}$ denotes bond holdings from time $t-1$ to time $t, R_{t}^{f}$ is the gross risk-free rate, and $W_{t}^{u}$ represents the frictionless wage (i.e. without wage rigidities, see also Uhlig (2007)). Hence, the household chooses the amount of hours allocated to labor as if the wage was not sticky. The first order conditions of the maximization

\footnotetext{
${ }^{4}$ Multiplying leisure by productivity in the utility flow also guarantees balanced growth.
} 
problem lead to the following expression for the stochastic discount factor (SDF)

$$
M_{t, t+1}=\beta\left(\frac{C_{t+1}}{C_{t}}\right)^{-1}\left(\frac{v_{t+1}}{v_{t}}\right)^{1-\frac{1}{\psi}}\left(\frac{U_{t+1}}{\left[\mathbb{E}_{t} U_{t+1}^{1-\gamma}\right]^{\frac{1}{1-\gamma}}}\right)^{\frac{1}{\psi}-\gamma} .
$$

The usual Euler equations of cum-dividend asset prices can be written as

$$
V_{C, t}=D_{C, t}+\mathbb{E}_{t}\left[M_{t, t+1} V_{C, t+1}\right], \quad V_{I, t}=D_{I, t}+\mathbb{E}_{t}\left[M_{t, t+1} V_{I, t+1}\right], \quad \frac{1}{R_{t}^{f}}=\mathbb{E}_{t}\left[M_{t, t+1}\right]
$$

Finally, the household's optimal labor allocation leads to

$$
W_{t}^{u}=\frac{1-\nu}{\nu} \frac{C_{t}}{1-L_{t}}
$$

\subsection{Consumption good sector}

The consumption good sector admits a representative perfectly competitive firm utilizing capital and labor to produce the consumption good. The production technology is given by

$$
Y_{C, t}=K_{C, t}^{\alpha_{C}}\left(A_{C, t} L_{C, t}\right)^{1-\alpha_{C}}
$$

where $\alpha_{C}$ is the capital share, labor $L_{C, t}$ is supplied by the household, and $A_{C, t}$ is the exogenous laboraugmenting productivity. We assume that $A_{C, t}$ is subject to both short- and long-run shocks:

$$
A_{C, t}=e^{a_{C, t}}, \quad a_{C, t}=\mu_{C}+x_{C, t-1}+a_{C, t-1}+\sigma_{C} \varepsilon_{C, t}, \quad x_{C, t}=\rho_{C} x_{C, t-1}+\sigma_{x, C} \varepsilon_{x, C, t} .
$$

The unconditional expected growth rate of productivity is $\mu_{C}$. Short-run productivity shocks are induced by $\varepsilon_{C, t}$, whereas $\varepsilon_{x, C, t}$ indicates long-run shocks which affect the stochastic component in expected productivity growth $x_{C, t}$. The persistence of long-run productivity shocks is measured by $\rho_{C}$. Moreover, capital $K_{C, t}$ accumulates according to

$$
K_{C, t+1}=\left(1-\delta_{K}\right) K_{C, t}+G\left(i_{C, t}\right) K_{C, t} .
$$


Here, $i_{C, t}=\frac{I_{C, t}}{K_{C, t}}$ and $\delta_{K}$ is the depreciation rate of capital. $G$ captures adjustment costs of investments as in Jermann (1998):

$$
G_{t}:=G\left(i_{C, t}\right)=\frac{\alpha_{1}}{1-\frac{1}{\tau}}\left(i_{C, t}\right)^{1-\frac{1}{\tau}}+\alpha_{2}
$$

where the constants $\alpha_{1}$ and $\alpha_{2}$ are chosen such that there are no adjustment costs in the deterministic steady state.

In the spirit of Justiniano et al. (2010) and Papanikolaou (2011) we assume that the marginal efficiency of investment goods is stochastic and governed by the process $Z_{M, t}$. In order to increase the future capital stock by an absolute amount $G\left(i_{c, t}\right) K_{C, t}$, the representative firm needs to buy $Z_{M, t}^{-1} I_{C, t}$ units of the investment good at the relative price $P_{I, t}$. Thus, the total investment cost is given by $Z_{M, t}^{-1} I_{C, t} P_{I, t}$. The $\log$ marginal efficiency of investment goods is stochastic and follows a strictly stationary AR(1)-process:

$$
\log \left(Z_{M, t}\right)=\rho_{M} \log \left(Z_{M, t-1}\right)+\sigma_{M} \varepsilon_{M, t}
$$

Importantly, in a robustness check, we will switch this channel off by setting $\sigma_{M}=0$ and analyze an economy with deterministic marginal efficiency. This helps us to assess how our model with long-run investment specific shocks performs relative to Justiniano et al. (2010) and Papanikolaou (2011).

The net profit of the consumption good sector, $D_{C, t}$, is given by output minus the expenditure on investment goods and wages:

$$
D_{C, t}=Y_{C, t}-Z_{M, t}^{-1} P_{I, t} I_{C, t}-W_{t} L_{C, t}
$$

The representative firm chooses labor, capital and investment to maximize the firm value, i.e., the firm solves

$$
V_{C, 0}=\max _{\left\{K_{C, t+1}, I_{C, t}, L_{C, t}\right\}_{t=0}^{t=\infty}} \sum_{t=0}^{\infty} \mathbb{E}_{0}\left[M_{0, t} D_{C, t}\right],
$$

subject to the capital accumulation constraint (4). The first-order condition with respect to $K_{C, t+1}$,

$$
1=\mathbb{E}_{t}\left[M_{t, t+1} \frac{1}{\lambda_{t}}\left(\frac{\alpha_{C} Y_{C, t+1}-Z_{M, t+1}^{-1} P_{I, t+1} I_{C, t+1}}{K_{C, t+1}}+\lambda_{t+1}\left(G_{t+1}+1-\delta_{K}\right)\right)\right]
$$

determines the price of the investment good $P_{I, t}$. 


\section{$2.3 \quad$ Investment good sector}

The investment good sector supplies investment goods to the consumption good sector. It is populated by a monopolistic representative firm selling the demanded goods at the price $P_{I, t}$. Investment goods are produced according to the technology

$$
Y_{I, t}=A_{I, t} L_{I, t}^{1-\alpha_{I}}
$$

where $L_{I, t}$ is labor supplied by the household, $1-\alpha_{I}$ is the labor share, and $A_{I, t}$ is the stochastic total factor productivity of the investment good sector, whose dynamics are given by the following process:

$$
A_{I, t}=e^{a_{I, t}}, \quad a_{I, t}=\mu_{I}+x_{I, t-1}+a_{I, t-1}+\sigma_{I} \varepsilon_{I, t}, \quad x_{I, t}=\rho_{I} x_{I, t-1}+\sigma_{x, I} \varepsilon_{x, I, t} .
$$

Thus, as in the consumption good sector, the productivity of the investment good sector is subject to both short-run $\left(\varepsilon_{I, t}\right)$ and long-run $\left(\varepsilon_{x, I, t}\right)$ shocks. The unconditional expected growth rate of investment good sector's productivity is denoted by $\mu_{I}$, and $\rho_{I}$ denotes the persistence of long-run investment shocks. As argued in the introduction, this specification can, for instance, be justified by the traditional economic theory of investment hysteresis (see Dixit (1992)). Firms which have invested in a certain project tend to stay in business longer than they actually should if their decision was based on a strict analysis of prices and average variable costs. Even worse, firms continue investing even when the underlying causes of investment are fully reversed. This suggests that productivity shocks to the investment sector may have long-lasting effects. Our idea is to capture these long-lasting effects by introducing a long-run component into the TFP process of the investment sector.

Besides this theoretical justification, we can also provide empirical evidence for the existence of a long-run component in the investment sector. ${ }^{5}$ A recently developed database by O'Mahony and Timmer (2009) reports the total factor productivity (TFP) at the sectoral level for the U.S. and several European countries. For annual U.S. data from 1977 to 2010, estimating the long-run risk component in each sector

\footnotetext{
${ }^{5}$ As argued by Müller and Watson (2013), long-run forecasting tends to be econometrically difficult. In this study we provide just a first attempt to detect long-run shocks both in the consumption and the investment good sector by using a standard state-space approach. A rigorous analysis on different methodologies estimating long-run risk components is beyond the scope of the paper. We leave this empirical challenge for future research.
} 
via a simple standard state-space model gives the following results: ${ }^{6}$

$$
\begin{aligned}
\Delta \operatorname{lnTFP} P_{C} & =0.009+x_{C, t-1}+\underbrace{\sigma_{C, t}^{s r}}_{3.103^{* * *}[0.000]} \times \varepsilon_{1, t} \\
x_{C, t}= & 0.785 \cdot x_{C, t-1}+\underbrace{\sigma_{C, t}^{l r}}_{0.763^{* * *}[0.000]} \times \varepsilon_{2, t} \\
\Delta \operatorname{lnTFP} P_{I} & =0.001+x_{I, t-1}+\underbrace{\sigma_{I, t}^{s r}}_{1.467^{* * *}[0.000]} \times \varepsilon_{3, t} \\
x_{I, t} & =0.785 \cdot x_{I, t-1}+\underbrace{\sigma_{I, t}^{l r}}_{1.251^{* * *}[0.000]} \times \varepsilon_{4, t},
\end{aligned}
$$

where $\sigma_{C, t}^{s r}, \sigma_{C, t}^{l r}, \sigma_{I, t}^{s r}$, and $\sigma_{I, t}^{l r} \sigma_{i, t}^{s r}$ are the estimated volatilities of short-run and long-run consumption and investment TFP shocks, and the $\varepsilon_{j, t}(j=1,2,3,4)$ are i.i.d. standard normal shocks. We have repeated the estimation with data from other developed countries. The results from this robustness check are reported in Appendix B and corroborate our findings.

The investment good sector pays wages to the household and its total output $Y_{I, t}$ is sold to the consumption good sector at the price $P_{I, t}$. The net profit of the investment good sector is therefore given by

$$
D_{I, t}=P_{I, t} Y_{I, t}-W_{t} L_{I, t}
$$

The investment good sector firm chooses labor $L_{I, t}$ to maximize the firm value:

$$
V_{I, 0}=\max _{\left\{L_{I, t}\right\}_{t=0}^{t=\infty}}\left\{\sum_{t=0}^{\infty} \mathbb{E}_{0}\left[M_{0, t} D_{I, t}\right]\right\}
$$

\subsection{Labor market frictions}

We assume that the labor supply is subject to frictions. In the spirit of Blanchard and Galí (2005) and Uhlig (2007), we impose that a fraction of the labor supply does not reach the market. As shown by

\footnotetext{
${ }^{6} \mathrm{p}$-values are reported in square brackets. $* * *$ indicates significance at the $0.1 \%$ level. In line with standard state-space estimations, the p-values refer to the null hypotheses that $\sigma_{C, t}^{s r}, \sigma_{C, t}^{l r}, \sigma_{I, t}^{s r}$, or $\sigma_{I, t}^{l r}$ are equal to zero and follow from the respective Z-statistics.
} 
Uhlig (2007), this results in sticky wages, i.e., households' wages are given by:

$$
W_{t}=\left(W_{t-1}\right)^{\xi}\left(W_{t}^{u}\right)^{1-\xi},
$$

where $W_{t}^{u}$ represents the frictionless wage. The intuition is that the household chooses labor hours as if there were no labor market frictions. Hence, $W_{t}^{u}$ appears in the household budget constraint (2). However, the actual salary paid to households is $W_{t}$, which therefore appears in the definition of firm's dividends (5), (7) and (9). The parameter $\xi$ controls the degree of wage rigidities. In particular, $\xi=0$ implies the absence of labor market rigidities.

\subsection{Market clearing conditions and aggregate dividends}

The household supplies labor to the consumption and the investment good sector. Thus, market clearing in the labor market dictates

$$
L_{t}=L_{C, t}+L_{I, t} .
$$

Equating the supply and demand for investment goods implies

$$
Z_{M, t}^{-1} I_{C, t}=Y_{I, t} .
$$

The output of the consumption good sector is fully consumed by the household and therefore the consumption good market clears when

$$
C_{t}=Y_{C, t}=W_{t} L_{t}+D_{M, t}=W_{t} L_{t}+D_{C, t}+D_{I, t} .
$$

The second equality is obtained by assuming that $i$ ) bonds are in zero net supply and the stocks of the consumption and the investment good sector firms are in unit supply (i.e. $B_{t} \equiv 0$ and $\vartheta_{C, t} \equiv \vartheta_{I, t} \equiv 1$ ), and $i$ i) households receive the actual wage $W_{t}$ in exchange for their labor supply and not the frictionless wage $W_{t}^{u}$. Furthermore, aggregate ("market") dividends, $D_{M, t}=D_{C, t}+D_{I, t}$, are given by the sum of the dividends distributed by the consumption and the investment good sector. The market value at time 
0 , which defines the aggregate equity premium in our economy, is consequently defined as

$$
V_{M, 0}=\sum_{t=0}^{\infty} \mathbb{E}_{0}\left[M_{0, t} D_{M, t}\right]
$$

\section{Benchmark Calibration}

We assume that the representative agent has a monthly decision interval. Therefore, we calibrate the model to a monthly frequency. In our benchmark two-sector production economy nineteen parameters need to be specified: four for preferences, seven relating to the consumption good sector $\mathrm{C}$, seven modeling the investment good sector I, and one accounting for the labor market friction. Our calibration is summarized in Table 1.

The preference parameters are set in accordance with the recent long-run risk literature. The subjective discount factor is set to 0.997 (implying an annualized value of 0.97 ) so as to help the model match the relatively low level of the risk-free rate observed in the data. We set the coefficient of relative risk aversion and elasticity of intertemporal substitution to values of 10 and 1.95, respectively. Similar values can be found in Bansal and Yaron (2004), Croce (2014), and Kung and Schmid (2015). Note that we have $\gamma>1 / \psi$. This implies that agents have a preference for early resolution of uncertainty, which is also in line with the recent experimental evidence by Brown and Kim (2014). Following standard practice, the consumption share in the utility bundle $\nu$ is chosen such that the steady state supply of labor is one third of the total time endowment of the household. Given the other parameters, this is achieved by setting $\nu=0.3514$.

We calibrate the parameters of the long-run risk processes, $x_{C, t}$ and $x_{I, t}$, to be in line with the literature on long-run risk. In particular, we fix the persistence of $x_{C, t}$ and $x_{I, t}$ to be $\rho_{C}=\rho_{I}=0.98$ as in Croce (2014). These values imply an annualized persistence of 0.80 which is in line with the state-space estimation above. As in Croce (2014), we set $\mu_{C}=\mu_{I}=0.018 / 12$ so that the average annual growth rate is 0.018 , consistent with US data. We fix the volatility of the long-run shocks to be a small percentage $(7.5 \%)$ of the volatility of the short-run shocks (see Bansal and Yaron (2004), Pancrazi (2014)). Thus, we impose $\sigma_{x, C}=0.075 \cdot \sigma_{C}$ and $\sigma_{x, I}=0.075 \cdot \sigma_{I}$. Finally, we set $\sigma_{C}=\sigma_{I}=0.02 / \sqrt{12}$ to match the annualized volatility of consumption growth which is around 0.02 in the data. The depreciation rate of physical capital in the consumption good sector is again standard and set to 0.085/12 as in Papanikolaou 
(2011). On the production side, also as in Papanikolaou (2011), we set the capital shares in consumption good production $\left(\alpha_{C}\right)$ and investment good production $\left(\alpha_{I}\right)$ equal to 0.3 and 0.1 , respectively.

Table 1: Monthly BenCHMARK CALIBRATION

\begin{tabular}{|c|c|c|c|}
\hline Parameter & Description & Source & Value \\
\hline \multicolumn{4}{|c|}{ PPREFERENCE PARAMETERS } \\
\hline$\beta$ & subjective discount factor & 6 & 0.997 \\
\hline$\gamma$ & risk aversion & $2 / 4$ & 10 \\
\hline$\psi$ & elasticity of intertemporal substitution & 6 & 1.95 \\
\hline$\nu$ & consumption share in utility bundle & 6 & 0.3514 \\
\hline \multicolumn{4}{|c|}{ CONSUMPTION GOOD SECTOR } \\
\hline \multicolumn{4}{|c|}{ Technology parameters } \\
\hline----- & capital share in consumption good production & $\overline{1}$ & $\overline{0} \overline{3}$ \\
\hline$\delta_{K}$ & depreciation rate of physical capital & 1 & $0.085 / 12$ \\
\hline$\tau$ & elasticity of adjustment costs in investment & 1 & 1.15 \\
\hline \multicolumn{4}{|c|}{ TFP parameters } \\
\hline $\begin{array}{c}------ \\
\mu_{C}\end{array}$ & long-run mean of consumption good sector TFP & -4 & $0.018 / 12$ \\
\hline$\sigma_{C}$ & volatility of short-run shocks to consumption good sector TFP $\varepsilon_{C}$ & 6 & $0.02 / \sqrt{12}$ \\
\hline$\rho_{C}$ & autocorrelation of long-run shocks to consumption good sector TFP $x_{C}$ & 4 & 0.98 \\
\hline$\sigma_{x, C}$ & volatility of long-run shocks to consumption good sector TFP $\varepsilon_{x, C}$ & 6 & $0.075 \cdot \sigma_{C}$ \\
\hline \multicolumn{4}{|c|}{ INVESTMENT GOOD SECTOR } \\
\hline \multirow{2}{*}{\multicolumn{4}{|c|}{$\begin{array}{l}\text { Technology parameters } \\
\alpha_{I} \quad \text { capital share in } \\
\text { TFP parameters }\end{array}$}} \\
\hline & & & \\
\hline------ & long-run mean of investment good sector $\overline{\mathrm{TFP}}^{-----}$ & $\overline{4}$ & $\overline{0} . \overline{0} \overline{1} \overline{8} / \overline{1} 2^{-}$ \\
\hline$\sigma_{I}$ & volatility of short-run shocks to investment good sector TFP $\varepsilon_{I}$ & 6 & $0.02 / \sqrt{12}$ \\
\hline$\rho_{I}$ & Autocorrelation of long-run shocks to investment good sector TFP $x_{I}$ & 4 & 0.98 \\
\hline$\sigma_{x, I}$ & volatility of long-run shocks to investment good sector TFP $\varepsilon_{x, I}$ & 6 & $0.075 \cdot \sigma_{I}$ \\
\hline $\bar{\sigma}_{M}^{-}$ & volatility of shocks to investment good efficiency $\varepsilon_{M}$ & $\overline{3}$ & $\overline{0 .} \cdot \overline{12} / \overline{\sqrt{12}}$ \\
\hline$\rho_{M}$ & autocorrelation of shocks to investment good efficiency $Z_{M}$ & 3 & 0.92 \\
\hline \multicolumn{4}{|c|}{ LABOR MARKET } \\
\hline$\xi$ & wage rigidity parameter & 5 & 0.35 \\
\hline
\end{tabular}

Notes: Parameters sources: 1=Papanikolaou (2011), 2=Kung and Schmid (2015), 3=Justiniano et al. (2010), 4=Croce (2014), 5=Uhlig (2007), 6=own calibration.

The elasticity of the supply curve of capital, $\tau$, is equal to 1.15, a value in line with existing empirical 
evidence. ${ }^{7}$ The parameters related to the marginal efficiency of investment are calibrated as in Justiniano et al. (2010). Therefore, we use $\sigma_{M}=0.12 / \sqrt{12}$ for its volatility and $\rho_{M}=0.92$, implying a very moderate annualized persistence of 0.37 (see also Furlanetto and Seneca (2014a)). Finally, following Uhlig (2007), we assume a moderate degree of wage stickiness by imposing $\xi=0.35$.

The model is solved in dynare++ 4.2.1 using a second-order approximation. Moments (reported in Section 4) are obtained from repetitions of small-sample simulations.

\section{Quantitative Results}

Table 2 reports the main results of the paper. We consider several sub-cases that allow us to analyze the role of the different model features for the macroeconomic and asset pricing dynamics. Panel A reports results for the role of long-run risk. First, we solve an economy without any long-run risk (Model 1). Then we introduce long-run risk in the consumption sector (Model 2), and finally we allow for long-run risk in both the consumption and the investment sector. In all cases we assume the absence of wage rigidities.

In the absence of long-run risk the model has difficulties in matching the basic properties of stock returns, most importantly the equity premium. ${ }^{8}$ However, the model reproduces the observed co-movements between consumption, labor and output. Introducing long-run risk in the consumption sector makes this sector relatively riskier (as compared to the case of no long-run risk), which leads to a substantial increase in the risk premium required to hold the consumption sector equity. The market equity premium thus increases from 0.43 to 3.47 percentage points. Introducing long-run risk in the investment sector further improves the asset pricing quantities, especially the stock return volatility of the investment sector. More precisely, the volatility spread between the investment and the consumption sector increases from 1.59 to 6.05 percentage points and gets closer to the value observed in the data (10.96 percentage points). Long-run risk in the investment sector affects only the expected return and volatility differential, but not the expected return of the market portfolio. The risk premium for the consumption sector decreases slightly and the risk premium for the investment sector increases slightly, which suggests that the long-

\footnotetext{
${ }^{7}$ Eberly (1997), for instance, reports estimates that range between 1.08 and 1.36. In an earlier empirical work, Abel (1980) reports values for $\tau$ ranging between 0.5 and 1.14.

${ }^{8}$ The market portfolio in all our quantitative results is defined as a claim to the sum of the consumption good sector dividends and the investment good sector dividends, see also Section 2.5.
} 


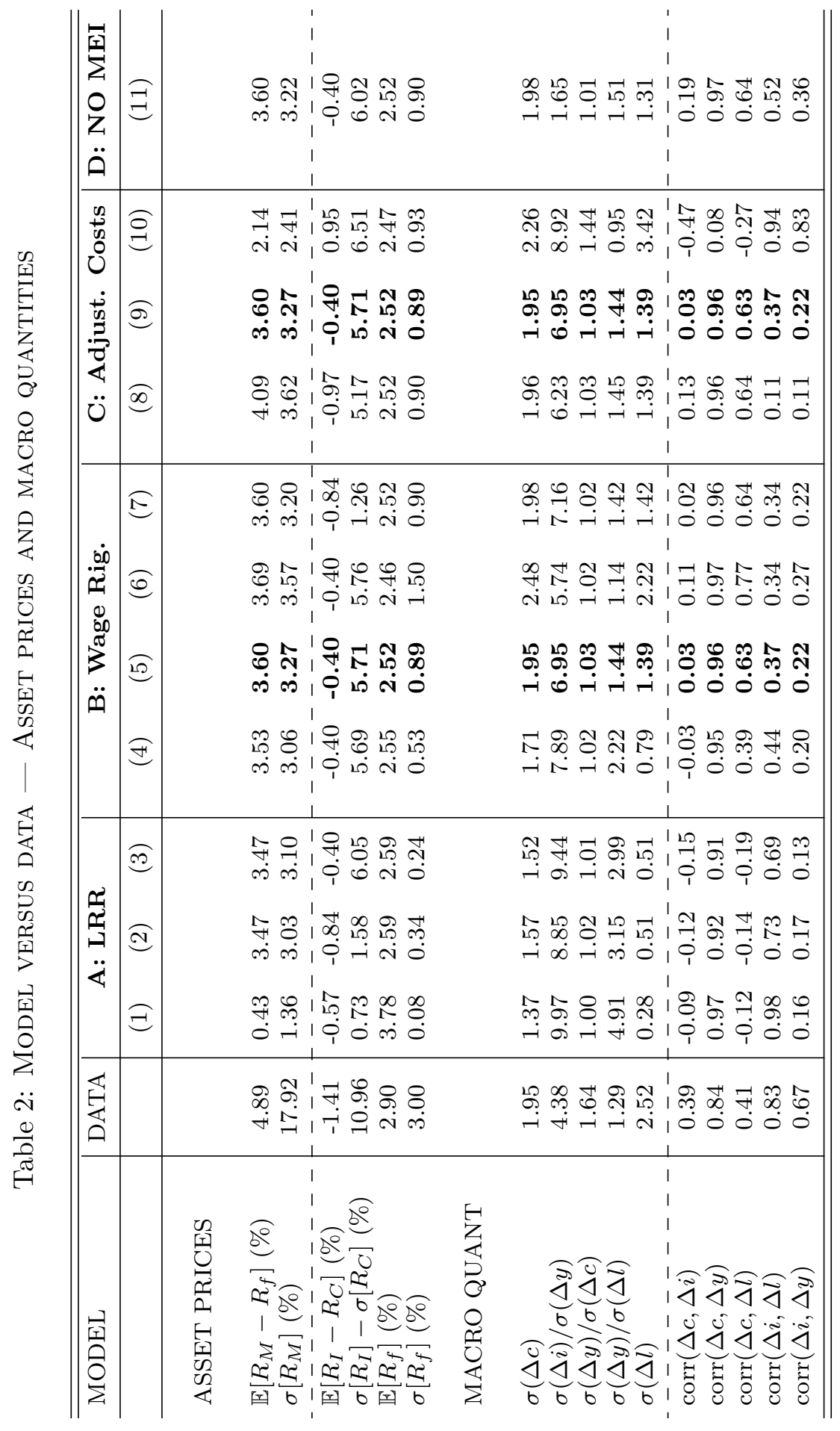

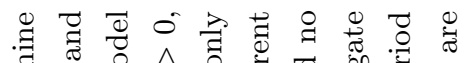

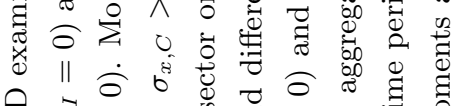

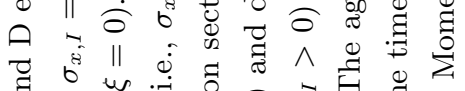
สี 0 u

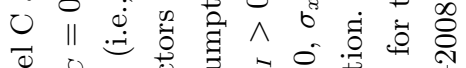
สำ 0 . : \& : क

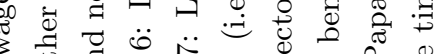
पे क्षै च ․․

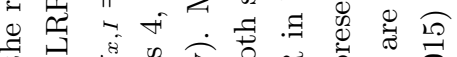

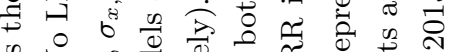

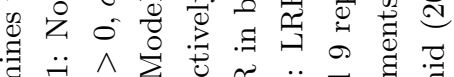

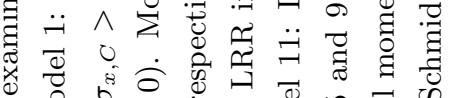
0 : 110 क

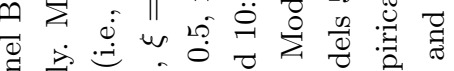

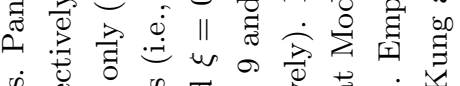
窇

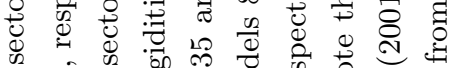
चี 苞苛

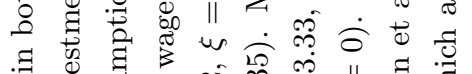

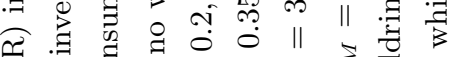
荡

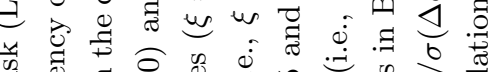

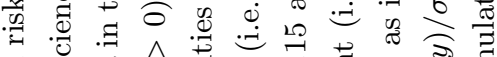

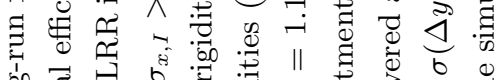

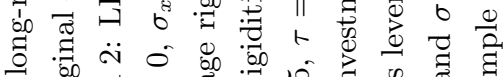
पै 荡

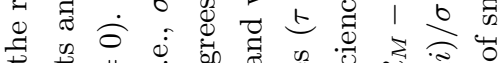
क

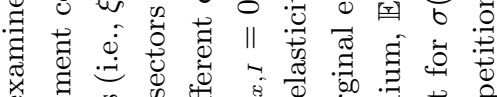
य

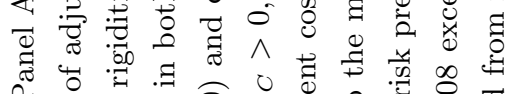

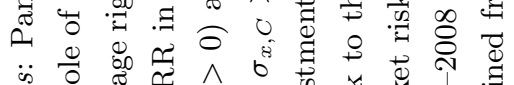

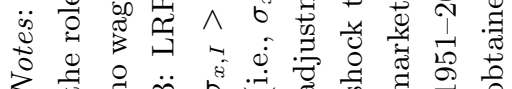


run risk component of investment shocks is priced by financial markets. Nevertheless, the risk premium is still higher for the consumption sector. This can be explained by differences in the cyclical variation between the two sectors: due to adjustment costs, consumption is more pro-cyclical than investments, i.e. $\operatorname{corr}(\Delta c, \Delta y)>\operatorname{corr}(\Delta i, \Delta y)$, and therefore riskier from an insurance point of view. In summary, this benchmark case shows that the long-run risk component of investment shocks is important to generate a realistic differential between the return volatility of the consumption and the investment sector. ${ }^{9}$ Key macroeconomic quantities remain qualitatively unchanged after the introduction of long-run risk in the investment sector. In particular, all calibrations in Panel A fail to explain the correlation between consumption and investment.

To address the co-movement problem we introduce wage rigidities. Results are reported in Panel $\mathrm{B}$ of Table 2. In this case, the unconditional correlation between consumption and investment switches sign and becomes positive. The economic mechanism behind this result can be explained from inspecting the impulse-response functions of key macroeconomic quantities. These are depicted in Appendix C. Intuitively, wage rigidities change the intertemporal substitution between consumption and labor. Importantly, this effect is different for the four types of productivity shocks in our model.

Consider first the effect of a positive short-run shock in the productivity of the investment sector. Such a shock increases the return on investment and gives households an incentive to invest more today and postpone consumption (Figure C.1, first and third row), which implies that consumption and investments move in opposite directions in response to short-run investment shocks. In contrast, investments decrease in response to long-run shocks in the productivity of the investment sector because of the interaction between the income effect and the substitution effect, i.e., because a positive shock to long-run productivity increases the continuation utility. As a result, households react to this long-run shock by reducing investment. This implies that consumption and investments move in the same direction in response to long-run shocks to the productivity of investments. Finally, consider the effect of consumption sector TFP shocks. As is known from Croce (2014), the wealth effect and the substitution effect work in opposite directions here. Consequently, investment and consumption move in the same direction in response to short-run shocks to the consumption TFP, while they move in opposite directions in response to long-run shocks to the consumption TFP.

\footnotetext{
${ }^{9}$ This is in line with Papanikolaou (2011) who shows that investment shocks generate differences in return volatilities due to their heterogeneous impact on different firms.
} 
Taken together, the natural question is then the following: can the negative co-movement between consumption and investment induced by short-run investment shocks and long-run consumption shocks be overcompensated by the positive co-movement resulting from the other two shocks in the economy, namely long-run investment shocks and short-run consumption shocks? We argue that the answer is yes, provided that wage rigidities are included in the model.

The reason for this is that wage rigidities increase the extent of positive co-movement between consumption and investment in response to long-run investment TFP shocks. To see this, note that wage rigidities reduce the wealth effect on labor supply. Hence, the now dominant substitution effect leads to a decrease in the labor supply when a long-run investment productivity shock materializes (see Figure C.1, fourth row), in contrast to the small increase we have seen without wage rigidities. This translates into a stronger decline in investment growth as compared to the case without wage rigidities. In summary, the stronger the wage rigidity, the stronger is the positive co-movement between consumption and investment in response to long-run investment shocks.

On the other hand, wage rigidities also alter the effect of short-run investment shocks and lead to simultaneous declines of consumption, output and labor hours growth when the short-run shock materializes. Since the impulse-response function of investment is insensitive to the degree of wage rigidities, this results in a more negative correlation between consumption and investment. Altogether, however, our results show that the stronger positive co-movement resulting from long-run investment shocks dominates the stronger negative co-movement from short-run investment shocks. The overall result is a positive correlation between consumption and investment as reported in Table 2, Panel B. In particular, note that this positive correlation is already obtained with very mild wage rigidities. ${ }^{10}$

Next, Panel C of Table 2 reports results about the role of adjustment costs. We choose two additional values for the adjustment costs elasticity, $\tau=0.95$ and $\tau=3.33$, which implies higher or lower adjustment costs than in the benchmark calibration $(\tau=1.15)$, respectively. ${ }^{11}$ The corresponding impulse-response functions are depicted in Figures C.2 and C.5. With lower adjustment costs (i.e., $\tau=3.33$ ), the model

\footnotetext{
${ }^{10}$ For instance, Furlanetto and Seneca (2014a) analyze the link between nominal rigidities and the positive co-movement across real variables in a DSGE model with shocks to the marginal efficiency of investment. They reproduce the positive co-movement between consumption and investment, but they assume stronger nominal rigidities than what microdata suggests.

${ }^{11}$ We stress that in our benchmark calibration the adjustment costs are smaller than in Jermann (1998) who imposes the elasticity of investment with respect to Tobin's Q to be equal to 0.23 (i.e., strong frictions). The introduction of a long-run component in both sectors, however, yields sizeable fluctuations in stock prices and investment even with a very mild friction.
} 
produces an extremely high investment growth volatility. As a result, the investment-output volatility ratio is equal to 8.92. In addition, due to the dominance of the short-run component in investment TFP and stronger opposite reactions of consumption and investment growth to these short-run investment shocks, investment becomes less correlated with consumption growth. In particular, the model generates a negative correlation of -0.47 between investment and consumption. This results in a lower aggregate equity risk premium, which is now only 2.14 percentage points. ${ }^{12}$ Similarly, with stronger frictions (i.e., $\tau=0.95$ ) , consumption and investment growth are more correlated than in the benchmark case (i.e., $\operatorname{corr}(\Delta c, \Delta i)=0.13)$. Consequently, the stock market is riskier, households demand an extra premium, and the aggregate equity risk premium rises to 4.09 percentage points (see also Jermann (1998) and Croce (2014)). As a result, the observed negative spread between the expected returns of the investment and the consumption sector can only be obtained with a sufficient degree of adjustment costs (i.e., $\tau=0.95$ or $\tau=1.15)$. The remaining asset pricing quantities are quite stable with respect to different choices of adjustment costs. Admittedly, a drawback of all our model specifications is the low volatility of aggregate excess returns, but this is a well-known issue of DSGE models. Some very recent asset pricing literature shows promising ideas of new economic channels which enable DSGE models to produce reasonable levels of return volatility. ${ }^{13}$ This is however beyond the scope of our paper.

In a last step, we now analyze the role of shocks to the marginal efficiency of investment. Papanikolaou (2011) shows that a standard model with i.i.d. TFP shocks and a deterministic marginal efficiency of investment cannot explain the basic properties of asset prices such as the equity premium and the return volatility spread unless an unrealistically large volatility of investment shocks is assumed. Panel D of Table 2 reports the results for our model when the marginal efficiency of investment is deterministic, i.e. $\sigma_{M}=0$. Importantly, the investment growth volatility (relative to the output growth volatility) is not matched correctly in this case. The other main properties of asset prices and macro quantities are however preserved even though we assume a realistically low volatility of TFP shocks. In other words,

\footnotetext{
${ }^{12}$ Note that the risk premium between $I$ and $C$ firms (i.e. $\mathbb{E}\left[R_{I}\right]-\mathbb{E}\left[R_{C}\right]$ ) becomes positive, suggesting that the amount of frictions affects mainly the consumption goods sector.

${ }^{13}$ For instance, Nezafat and Slavík (2015) develop a rich model that generates a sizeable stock market volatility through financial shocks affecting the tightness of firms' financing constraints. Croce (2014) obtains a volatility of about $11 \%$ by assuming a very high persistence of the long-run productivity shock ( 0.95 annually). Favilukis and Lin (2016) obtain values of similar magnitude with labor rigidities in the form of infrequent renegotiation of wages. Papanikolaou (2011) needs to assume a relatively large value for the volatility of shocks to the marginal efficiency of investments or for the volatility of investment productivity shocks. Kung and Schmid (2015) obtain a volatility of only about 0.03 (or about 0.06 in a high volatility calibration) in an endogenous growth model.
} 
the decisive economic mechanism in our model is long-run risk in the investment sector TFP and not the stochastic marginal efficiency of investment. On the one hand, our results therefore complement those of Papanikolaou (2011) because we provide a different economic explanation for the dynamics of asset prices. On the other hand, our results also extend his findings along two dimensions. First, our key economic mechanism, namely long-run risk in the productivity of the investment sector, does not only explain the dynamics of asset prices, but also macroeconomic co-movements when coupled with moderate wage rigidities. Second, the assumption of long-run investment-specific risk can be tested empirically and we provide evidence supporting the presence of such a long-run component in the TFP process of the investment sector.

\section{Conclusion}

The recent asset pricing and macroeconomic literature has proposed investment shocks as the main driver of asset prices and macroeconomic dynamics. However, as shown by Papanikolaou (2011), shocks to the total factor productivity of the investment sector cannot account for the high equity premium and the return volatility differential between the consumption and the investment sector unless coupled with shocks to the marginal efficiency of investments. In this paper we argue that shocks to the marginal efficiency of investments can be replaced by long-run risk in the total factor productivity of the investment sector without affecting the ability of the model to explain key features of asset prices. Our productionbased asset pricing model with long-run productivity risk, capital adjustment costs and wage rigidities replicates the equity premium, the stock return volatility differential between the consumption and the investment sector, the positive co-movement between consumption and investment growth and the high volatility of investment growth. Our paper thus adds to the, up until now and to the best of our knowledge, very thin literature that examines the joint implications of investment shocks on the dynamics of financial and macroeconomic quantities.

Naturally one can debate which one of the two approaches describes the statistical properties of the investment sector in a more realistic way. But more importantly, the two approaches offer different explanations for the economic link between the risk of the investment sector and asset prices. Shocks to the marginal efficiency of investments affect output and asset prices "only to the extent that they are implemented through the formation of new capital stock" (Papanikolaou (2011)). Differently, investment 
shocks alter the perception regarding long-term productivity, and this effect, which goes above and beyond the effect of investment shocks for the cost of producing new capital, is important for explaining the riskreturn differential between the consumption and the investment sector. This explanation is not only in line with the theory of investment hysteresis, but is also corroborated by empirical estimates of sectoral productivity processes. We thus think that long-run investment shocks are a very natural modeling choice given the empirical evidence.

Despite long-run productivity risk being intuitive and economically appealing, it has difficulties to account for the joint behavior of macroeconomic co-movements and asset pricing moments. In particular, consumption and investment tend to move in opposite directions in reaction to short-run investment shocks. This effect is quantitatively important and cannot be compensated by the other shocks in the economy. As a result, the unconditional correlation between consumption and investment is negative, in contrast to the empirical evidence. However, our analysis shows that moderate wage rigidities make consumption and investment less responsive to short-run investment shocks. This implies that, in the presence of wage rigidities, the negative co-movement between consumption and investment induced by short-run investment shocks can be compensated by positive co-movement resulting from long-run investment shocks. The unconditional correlation between consumption and investment then becomes positive, consistent with empirical evidence. Altogether, these results suggest that investment shocks can contribute a great deal to explaining the dynamics of asset prices, but need to be coupled with nominal rigidities (or other sources of market imperfections) to generate realistic macroeconomic co-movements. 


\section{References}

Abel, A., 1980. Empirical Investment Equations: An Integrative Framework. Carnegie-Rochester Conference Series on Public Policy.

Bansal, R., Yaron, A., 2004. Risks for the Long Run: A Potential Resolution of Asset Pricing Puzzles. Journal of Finance 59, 1481-1509.

Bar-Ilan, A., Strange, W. C., 1996. Investment Lags. American Economic Review 86, 610-622.

Bar-Ilan, A., Strange, W. C., 1999. The Timing and Intensity of Investment. Journal of Macroeconomics $21,57-77$.

Barham, B. L., Chavas, J., T., C. O., 1998. Sunk Costs and the Natural Resource Extraction Sector: Analytical Models and Historical Examples of Hysteresis and Strategic Behavior in the Americas. Land Economics 74, 429-448.

Barro, R., 2006. Rare Disasters and Asset Markets in the Twentieth Century. Quarterly Journal of Economics 121, 823-866.

Bernanke, B., 1983. Irreversibility, Uncertainty, and Cyclical Investment. The Quarterly Journal of Economics $98,85-106$.

Blanchard, O., Galí, J., 2005. Real Wage Rigidities and the New Keynesian Model. NBER Working Paper No. 11806.

Boldrin, M., Christiano, L. J., Fisher, J. D., 2001. Habit Persistence, Asset Returns and the Business Cycle. American Economic Review 91, 149-166.

Bragger, D., Bragger, J. D., A., H. D., Kirnan, J., 2003. When Success Breeds Failure: History, Hysteresis, and Delayed Exit Decisions. Journal of Applied Psychology 88, 6-14.

Brown, A. L., Kim, H., 2014. Do Individuals Have Preferences Used in Macro-Finance Models? An Experimental Investigation. Management Science 60, 939-958.

Croce, M. M., 2014. Long-Run Productivity Risk: A New Hope for Production-Based Asset Pricing? Journal of Monetary Economics 66, 13-31. 
Dixit, A., 1989. Entry and Exit Decisions under Uncertainty. Journal of Political Economy 97, 620-638.

Dixit, A., 1992. Investment and Hysteresis. Journal of Economic Perspectives 6, 107-132.

Eberly, J., 1997. International Evidence on investment and Fundamentals. European Economic Review 41, 1055-1078.

Edge, R. M., Laubach, T., Williams, J. C., 2007. Learning and shifts in long-run productivity growth. Journal of Monetary Economics 54, 2421-2438.

Epstein, L., Zin, S., 1989. Substitution, Risk Aversion, and the Temporal Behavior of Consumption Growth and Asset Returns I: A Theoretical Framework. Econometrica 57, 937-969.

Favilukis, J., Lin, X., 2016. Wage Rigidity: A Quantitative Solution to Several Asset Pricing Puzzles. Review of Financial Studies 29, 148-192.

Furlanetto, F., Natvik, G. J., Seneca, M., 2013. Investment Shocks and Macroeconomic co-movement. Journal of Macroeconomics 37, 208-216.

Furlanetto, F., Seneca, M., 2014a. Investment Shocks and Consumption. European Economic Review 66, $111-126$.

Furlanetto, F., Seneca, M., 2014b. New Perspectives on Depreciation Shocks as a source of Business Cycle Fluctuations. Macroeconomic Dynamics 18, 1209-1233.

Garlappi, L., Song, Z., 2013. Market Power and Capital Flexibility: A New Perspective on the Pricing of Technology Shocks. Working Paper.

Greenwood, J., Hercowitz, Z., Krusell, P., 2000. The Role of Investment-Specific Technological Change in the Business Cycle. European Economic Review 44, 91-115.

Hinrichs, J., Muhoff, O., M., O., 2008. Economic Hysteresis in Hog Production. Applied Economics 40, 333-340.

Jermann, U. J., 1998. Asset Pricing in Production Economies. Journal of Monetary Economics 41, 257275. 
Justiniano, A., Primiceri, G. E., Tambalotti, A., 2010. Investment Shocks and Business Cycles. Journal of Monetary Economics 57, 132-145.

Justiniano, A., Primiceri, G. E., Tambalotti, A., 2011. Investment Shocks and the Relative Price of Investments. Review of Economic Dynamics 14, 102-121.

Khan, H., Tsoukalas, J., 2011. Investment Shocks and the Comovement Problem. Journal of Economic Dynamics and Control 35, 115-130.

Kogan, L., 2001. An equilibrium model of irreversible investment. Journal of Financial Economics 62, 201-245.

Kogan, L., Papanikolaou, D., 2014. Growth Opportunities, Technology Shocks, and Asset Prices. Journal of Finance 69, 675-718.

Kogan, L., Papanikolaou, D., Stoffman, N., 2015. Winners and Losers: Creative Destruction and the Stock Market. Working Paper.

Kogut, B., Chang, S., 1996. Platform Investments and Volatile Exchange Rates: Direct Investment in the U.S. by Japanese Electronic Companies. The Review of Economics and Statistics 78, 221-231.

Kung, H., Schmid, L., 2015. Innovation, growth, and asset prices. Journal of Finance 70, 1001-1037.

Müller, U. K., Watson, M. W., 2013. Measuring Uncertainty about Long-Run Predictions. Working Paper.

Musshoff, O., M., O., Schade, C., S., M.-N., Sandri, S., 2013. Inertia in disinvestment decisions: experimental evidence. European Review of Agricultural Economics 40, 463-485.

Nezafat, M., Slavík, C., 2015. Asset Prices and Business Cycles with Financial Shocks. Working Paper.

O'Mahony, M., Timmer, M., 2009. Output, Input and Productivity Measures at the Industry Level: the EU KLEMS Database. Economic Journal 119, 374-403.

Pancrazi, R., 2014. How Beneficial Was the Great Moderation After All? Journal of Economic Dynamics and Control 46, 73-90. 
Papanikolaou, D., 2011. Investment Shocks and Asset Prices. Journal of Political Economy 119, 639-685.

Petrosky-Nadeau, N., Zhang, L., Kuehn, L. A., 2015. Endogenous disasters and asset prices. Working Paper.

Richard, T., Green, G., 2003. Economic Hysteresis in Variety Selection. Journal of Agricultural and Applied Economics 35, 1-14.

Sudo, N., 2012. Sectoral Comovement, Monetary Policy Shocks, and Input-Output Structure. Journal of Money, Credit and Banking 44, 1225-1244.

Uhlig, H., 2007. Explaining Asset Prices with External Habits and Wage Rigidities in a DSGE Model. American Economic Review 97, 239-243. 


\section{A Equilibrium}

The equilibrium allocation in this economy consists of (i) time paths of consumption, total labor hours, labor hours supplied to the consumption good sector and investment good sector, and utility flow $\left\{C_{t}, L_{t}, L_{C, t}, L_{I, t}, v_{t}\right\}_{t=0}^{t=\infty}$, (ii) time paths of consumption good output, physical capital, investment and new capital created $\left\{Y_{C, t}, K_{C, t}, I_{C, t}, G_{t}\right\}_{t=0}^{t=\infty}$, (iii) time paths of investment good output and investment good price $\left\{Y_{I, t}, P_{I, t}\right\}_{t=0}^{t=\infty}$, (iv) time paths of dividends and cum-dividend stock prices for the consumption and investment good sector, as well as the aggregate market $\left\{D_{C, t}, V_{C, t}, D_{I, t}, V_{I, t}, D_{M, t}, V_{M, t}\right\}_{t=0}^{t=\infty}$ and (v) time paths of the pricing kernel in consumption and utility flow units, the wealth to utility flow ratio, the return on wealth and the risk-free rate $\left\{M_{t, t+1}, M_{t, t+1}^{(v)}, u_{t}, R_{t}^{W}, R_{f, t}\right\}_{t=0}^{t=\infty}$, such that (a) the representative household maximizes lifetime utility (1), (b) the consumption good sector maximizes its value (6) and (c) the investment good sector maximizes its value (8).

This implies that the equilibrium is determined by a system of 25 equations for 25 variables, $v_{t}, R_{t}^{W}$, $C_{t}, L_{t}, L_{C, t}, L_{I, t}, W_{t}^{u}, W_{t}, Y_{C, t}, Y_{I, t}, K_{C, t}, I_{C, t}, P_{I, t}, \lambda_{t}, M_{t, t+1}, M_{t, t+1}^{(v)}, u_{t}, D_{C, t}, V_{C, t}, D_{I, t}, V_{I, t}$, $D_{M, t}, V_{M, t}, G_{t}$ and $R_{f, t}$, given the endogenous state variable $K_{C, t}$ and five exogenous state variables $A_{C, t}, A_{I, t}, Z_{M, t}, x_{C, t}, x_{I, t}$. The equations to be solved can be grouped as follows:

1. Conditions for the household's maximization problem and related Euler equations:

$$
\begin{aligned}
W_{t}^{u} & =\frac{1-\nu}{\nu}\left(\frac{C_{t}}{1-L_{t}}\right) \\
W_{t} & =\left(W_{t-1}\right)^{\xi}\left(W_{t}^{u}\right)^{1-\xi} \\
v_{t} & =C_{t}^{\nu}\left(A_{C, t}\left(1-L_{t}\right)\right)^{1-\nu} \\
u_{t} & =1+\mathbb{E}_{t}\left[M_{t, t+1}^{(v)} u_{t+1} \frac{v_{t+1}}{v_{t}}\right] \\
R_{t}^{W} & =\frac{u_{t}+\frac{v_{t}}{v_{t-1}}}{u_{t-1}-1} \\
M_{t, t+1} & =\beta\left(\frac{C_{t+1}}{C_{t}}\right)^{-1}\left(\frac{v_{t+1}}{v_{t}}\right)^{1-\frac{1}{\psi}}\left(\frac{U_{t+1}}{\left[\mathbb{E}_{t} U_{t+1}^{1-\gamma}\right]^{\frac{1}{1-\gamma}}}\right)^{\frac{1}{\psi}-\gamma}=\beta^{\theta}\left(\frac{v_{t+1}}{v_{t}}\right)^{1-\frac{\theta}{\psi}}\left(\frac{C_{t+1}}{C_{t}}\right)^{-1}\left(R_{t+1}^{W}\right)^{\theta-1} \\
M_{t, t+1}^{(v)} & =\beta^{\theta}\left(\frac{v_{t+1}}{v_{t}}\right)^{-\frac{\theta}{\psi}}\left(R_{t+1}^{W}\right)^{\theta-1} \\
\frac{1}{R_{t}^{f}} & =\mathbb{E}_{t}\left[M_{t, t+1}\right] .
\end{aligned}
$$


2. Conditions for the maximization problem of the consumption good firm and related equations:

$$
\begin{aligned}
W_{t} & =\frac{\left(1-\alpha_{C}\right) Y_{C, t}}{L_{C, t}} \\
Y_{C, t} & =K_{C, t}^{\alpha_{C}}\left(A_{C, t} L_{C, t}\right)^{1-\alpha_{C}} \\
K_{C, t+1} & =\left(1-\delta_{K}\right) K_{C, t}+G_{t} K_{C, t} \\
G_{t} & =\frac{\alpha_{1}}{1-\frac{1}{\tau}}\left(\frac{I_{C, t}}{K_{C, t}}\right)^{1-\frac{1}{\tau}}+\alpha_{2} \\
1 & =\mathbb{E}_{t}\left[M_{t, t+1} \frac{1}{\lambda_{t}}\left(\frac{\alpha_{C} Y_{C, t+1}-Z_{M, t+1}^{-1} P_{I, t+1} I_{C, t+1}}{K_{C, t+1}}+\lambda_{t+1}\left(G_{t+1}+1-\delta_{K}\right)\right)\right] \\
\lambda_{t} & =\frac{P_{I, t} Z_{M, t}^{-1}}{G_{t}^{\prime}} \\
D_{C, t} & =Y_{C, t}-Z_{M, t}^{-1} P_{I, t} I_{C, t}-W_{t} L_{C, t} \\
V_{C, t} & =D_{C, t}+\mathbb{E}_{t}\left[M_{t, t+1} V_{C, t+1}\right] .
\end{aligned}
$$

3. Conditions for the maximization problem of the investment good firm and related equations:

$$
\begin{aligned}
W_{t} & =\frac{\left(1-\alpha_{I}\right) P_{I, t} Y_{I, t}}{L_{I, t}} \\
Y_{I, t} & =A_{I, t} L_{I, t}^{1-\alpha_{I}} \\
D_{I, t} & =P_{I, t} Y_{I, t}-W_{t} L_{I, t} \\
V_{I, t} & =D_{I, t}+\mathbb{E}_{t}\left[M_{t, t+1} V_{I, t+1}\right] .
\end{aligned}
$$

4. Market clearing conditions and aggregate dividend:

$$
\begin{aligned}
L_{t} & =L_{C, t}+L_{I, t} \\
Y_{I, t} & =Z_{M, t}^{-1} I_{C, t} \\
C_{t} & =Y_{C, t}=W_{t} L_{t}+D_{M, t}=W_{t} L_{t}+D_{C, t}+D_{I, t} \\
D_{M, t} & =D_{C, t}+D_{I, t} \\
V_{M, t} & =D_{M, t}+\mathbb{E}_{t}\left[M_{t, t+1} V_{M, t+1}\right] .
\end{aligned}
$$


5. Evolution of the five exogenous state variables:

$$
\begin{aligned}
\log \left(A_{C, t}\right) & =\mu_{C}+x_{C, t-1}+\log \left(A_{C, t-1}\right)+\sigma_{C} \varepsilon_{C, t} \\
x_{C, t} & =\rho_{C} x_{C, t-1}+\sigma_{x, C} \varepsilon_{x, C, t} \\
\log \left(A_{I, t}\right) & =\mu_{I}+x_{I, t-1}+\log \left(A_{I, t-1}\right)+\sigma_{I} \varepsilon_{I, t} \\
x_{I, t} & =\rho_{I} x_{I, t-1}+\sigma_{x, I} \varepsilon_{x, I, t} \\
Z_{M, t} & =\rho_{M} Z_{M, t-1}+\sigma_{M} \varepsilon_{M, t} .
\end{aligned}
$$

\section{B Estimating Sectoral Productivity Shocks}

Sectoral total factor productivities are retrieved from the EU KLEMS database. Data is available for 34 industries, which are classified following the new international ISIC Revision 4 industry classification (consistent with the European NACE 2 industry classification). Industry-level data is provided for the following countries: Austria, Belgium, Finland, France, Germany, Italy, Japan, Netherlands, Spain, Sweden, UK and United States. Data is on an annual basis and covers the period 1977-2010. A summary of the construction of the EU KLEMS database can be found in O'Mahony and Timmer (2009).

Using the EU KLEMS database, we proxy the consumption sector productivity, $T F P_{C}$, and the investment sector productivity, $T F P_{I}$, in the following way:

- TFP : TOTAL MANUFACTURING, ELECTRICITY, GAS AND WATER SUPPLY, WHOLESALE AND RETAIL TRADE (cross-sector average)

- $T F P_{I}$ : CONSTRUCTION, FINANCIAL AND INSURANCE ACTIVITIES, INFORMATION AND COMMUNICATION, TRANSPORTATION (cross-sector average)

The estimations of the short-run and long-run shocks in each sector $S=C, I$ are then carried out via a state-space model which takes the following standard form:

$$
\begin{aligned}
\Delta \operatorname{lnTFP} P_{S} & =\hat{\mu}_{S}+x_{S, t-1}+\epsilon_{S, t}^{s r} \\
x_{S, t} & =\bar{\rho}_{S} z_{S, t-1}+\epsilon_{S, t}^{l r} .
\end{aligned}
$$

Estimation results for each country are reported in Table B.1. 
Table B.1: Cross-SECTOR SHORT-RUN AND LONG-RUN SHOCKS

\begin{tabular}{|c|c|c|c|c|c|c|c|c|}
\hline & \multicolumn{4}{|c|}{ CONSUMPTION GOODS SECTOR } & \multicolumn{4}{|c|}{ INVESTMENT GOODS SECTOR } \\
\hline Parameter & $\hat{\mu}_{C}$ & $\bar{\rho}_{C}$ & $\sigma\left(\epsilon_{C}^{s r}\right)$ & $\sigma\left(\epsilon_{C}^{l r}\right)$ & $\hat{\mu}_{I}$ & $\bar{\rho}_{I}$ & $\sigma\left(\epsilon_{I}^{s r}\right)$ & $\sigma\left(\epsilon_{I}^{l r}\right)$ \\
\hline $\begin{array}{l}\text { BELGIUM } \\
(1980-2009)\end{array}$ & 0.000 & 0.725 & $\begin{array}{c}1.677^{* * *} \\
{[0.000]}\end{array}$ & $\begin{array}{c}0.000 \\
{[0.999]}\end{array}$ & 0.009 & 0.725 & $\begin{array}{c}2.768^{* * *} \\
{[0.000]}\end{array}$ & $\begin{array}{c}0.000 \\
{[0.999]}\end{array}$ \\
\hline $\begin{array}{l}\text { FRANCE } \\
(1980-2009)\end{array}$ & 0.013 & 0.785 & $\begin{array}{c}0.548^{* * *} \\
{[0.001]}\end{array}$ & $\begin{array}{c}1.827^{* * *} \\
{[0.000]}\end{array}$ & 0.010 & 0.785 & $\begin{array}{c}1.612^{* * *} \\
{[0.000]}\end{array}$ & $\begin{array}{c}0.601^{* * *} \\
{[0.000]}\end{array}$ \\
\hline $\begin{array}{l}\text { GERMANY } \\
(1970-2009)\end{array}$ & 0.011 & 0.725 & $\begin{array}{c}2.497^{* * *} \\
{[0.000]}\end{array}$ & $\begin{array}{l}0.000 \\
{[0.999]}\end{array}$ & 0.01 & 0.725 & $\begin{array}{c}2.458^{* * *} \\
{[0.000]}\end{array}$ & $\begin{array}{c}0.000 \\
{[0.999]}\end{array}$ \\
\hline $\begin{array}{l}\text { ITALY } \\
(1971-2009)\end{array}$ & -0.003 & 0.725 & $\begin{array}{c}3.931^{* * * *} \\
{[0.000]}\end{array}$ & $\begin{array}{c}0.000 \\
{[0.998]}\end{array}$ & -0.003 & 0.785 & $\begin{array}{c}1.874^{* * *} \\
{[0.000]}\end{array}$ & $\begin{array}{c}0.725^{* * *} \\
{[0.000]}\end{array}$ \\
\hline $\begin{array}{l}\text { JAPAN } \\
(1973-2009)\end{array}$ & 0.018 & 0.785 & $\begin{array}{c}0.000 \\
{[0.998]}\end{array}$ & $\begin{array}{c}3.047^{* * *} \\
{[0.000]}\end{array}$ & 0.002 & 0.785 & $\begin{array}{c}2.421^{* * *} \\
{[0.000]}\end{array}$ & $\begin{array}{c}0.691^{* * *} \\
{[0.000]}\end{array}$ \\
\hline $\begin{array}{l}\text { SPAIN } \\
(1980-2009)\end{array}$ & 0.005 & 0.785 & $\begin{array}{c}1.404^{* * *} \\
{[0.000]}\end{array}$ & $\begin{array}{c}0.289^{* * *} \\
{[0.000]}\end{array}$ & 0.002 & 0.785 & $\begin{array}{c}1.639^{* * *} \\
{[0.000]}\end{array}$ & $\begin{array}{c}0.929^{* * *} \\
{[0.000]}\end{array}$ \\
\hline $\begin{array}{l}\text { NLD } \\
(1979-2009)\end{array}$ & 0.0133 & 0.785 & $\begin{array}{c}2.097^{* * * *} \\
{[0.000]}\end{array}$ & $\begin{array}{c}0.000 \\
{[0.999]}\end{array}$ & 0.001 & 0.785 & $\begin{array}{c}2.513^{* * *} \\
{[0.000]}\end{array}$ & $\begin{array}{c}0.542^{* * *} \\
{[0.001]}\end{array}$ \\
\hline $\begin{array}{l}\text { UK } \\
(1972-2009)\end{array}$ & 0.009 & 0.785 & $\begin{array}{c}2.502^{* * *} \\
{[0.000]}\end{array}$ & $\begin{array}{c}0.905^{* * *} \\
{[0.000]}\end{array}$ & 0.004 & 0.785 & $\begin{array}{c}2.557^{* * *} \\
{[0.000]}\end{array}$ & $\begin{array}{c}0.000 \\
{[0.997]}\end{array}$ \\
\hline $\begin{array}{l}\text { U.S. } \\
(1977-2009)\end{array}$ & 0.009 & 0.785 & $\begin{array}{c}3.103^{* * *} \\
{[0.000]}\end{array}$ & $\begin{array}{c}0.763^{* * *} \\
{[0.000]}\end{array}$ & 0.000 & 0.785 & $\begin{array}{c}1.467^{* * *} \\
{[0.000]}\end{array}$ & $\begin{array}{c}1.251^{* * *} \\
{[0.000]}\end{array}$ \\
\hline $\begin{array}{l}\text { EU } \\
(1981-2007)\end{array}$ & 0.013 & 0.785 & $\begin{array}{c}1.294^{* * *} \\
{[0.000]}\end{array}$ & $\begin{array}{c}0.000 \\
{[0.999]}\end{array}$ & 0.006 & 0.785 & $\begin{array}{c}0.650 * * * \\
{[0.000]}\end{array}$ & $\begin{array}{c}0.226^{* * *} \\
{[0.000]}\end{array}$ \\
\hline
\end{tabular}

Notes: $\hat{\mu}_{C}$ and $\hat{\mu}_{I}$ represent the estimated mean of the TFP growth in sector $C$ and $I$, respectively. The persistence parameter of the long-run component in both sectors is assumed to be fixed. EU represents the Eurozone countries for which growth accounting could be performed, namely: AUT, BEL, ESP, FIN, FRA, GER, ITA and NLD (Source: EU KLEMS Growth and Productivity Accounts: November 2009 release, updated March 2011). p-values are reported in square brackets. ${ }^{* * *}$ indicates significance at the $0.1 \%$ level.

\section{Impulse-Response Functions}

This appendix summarizes impulse-response functions from our model. In Appendix C.1 impulse response functions for investment-specific shocks are depicted. First, the effects of investment productivity shocks for different values of the degree of wage rigidity $\xi$ (see Figure C.1) and for different values of the elasticity of capital adjustment $\operatorname{costs} \tau$ (see Figure C.2) are depicted. Next, the impulse responses for a shock to the marginal efficiency of investments are depicted for different values of $\xi$ and $\tau$ in Figure C.3. In Appendix C.2 we summarize impulse response functions for consumption sector productivity shocks (in Figure C.4 for different values of $\xi$ and in Figure C.5 for different values of $\tau$ ). 


\section{C.1 Investment-specific shocks}

Figure C.1: Investment SeCtor Shocks: The Role of WAGe Rigidities
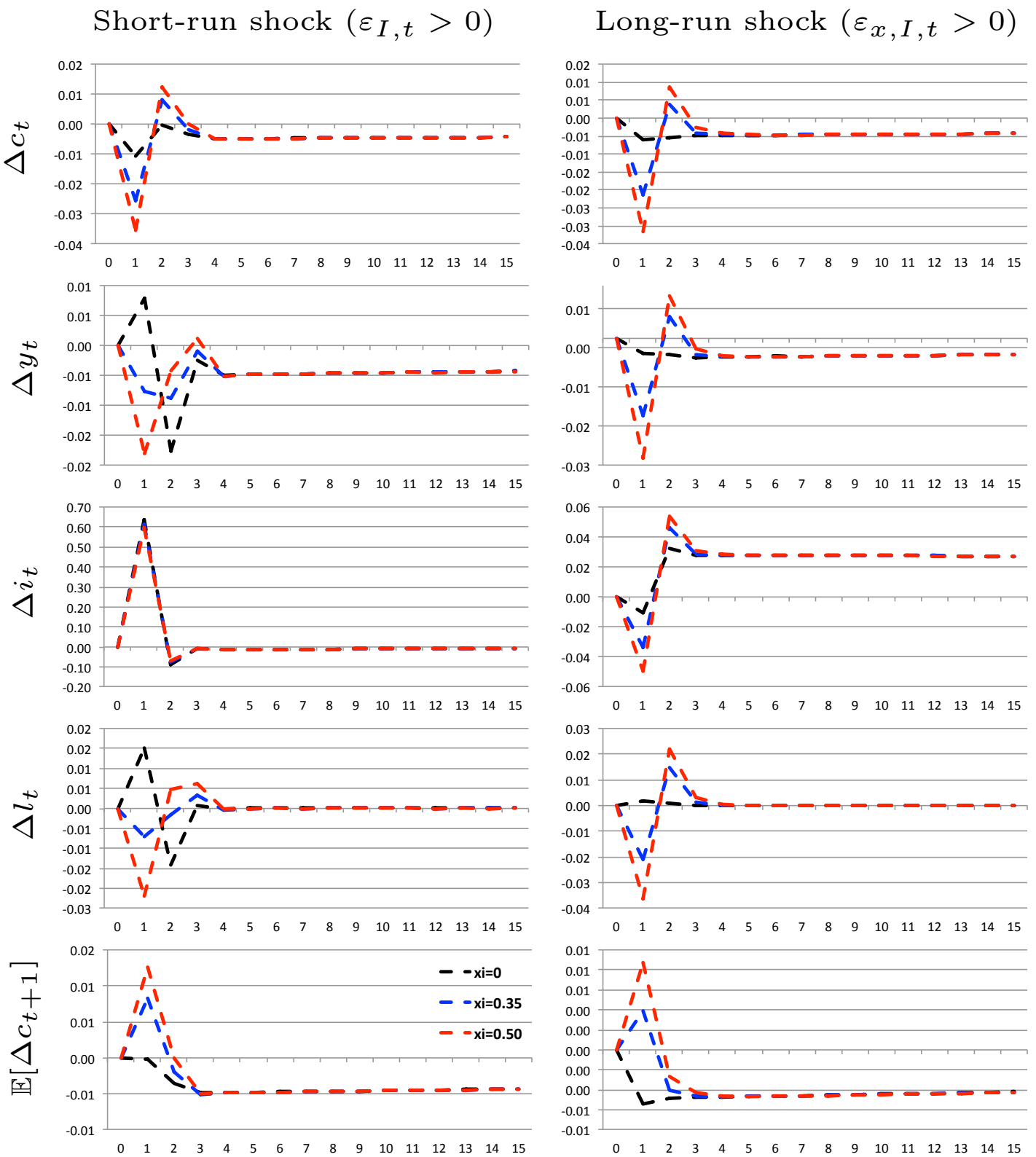

Notes: This figure depicts the impulse-response functions for a length of 15 months of log consumption growth $\Delta c_{t}$, $\log$ output growth $\Delta y_{t}, \log$ investment growth $\Delta i_{t}, \log$ labor growth $\Delta l_{t}$, and expected log consumption growth $\mathbb{E}_{t}\left[\Delta c_{t+1}\right]$. Impulse-response functions with respect to a positive one-standard-deviation short-run shock to investment sector TFP $\varepsilon_{I, t}$ and to a positive one-standard-deviation long-run shock to investment sector TFP $\varepsilon_{x, I, t}$ are depicted. Moreover, three different degrees of wage rigidities $(\xi=0, \xi=0.35$, and $\xi=0.5)$ are used. The values reported are deviations from the steady state in percentage points. 
Figure C.2: Investment SeCtor Shocks: The Role of ADJustment COSTS

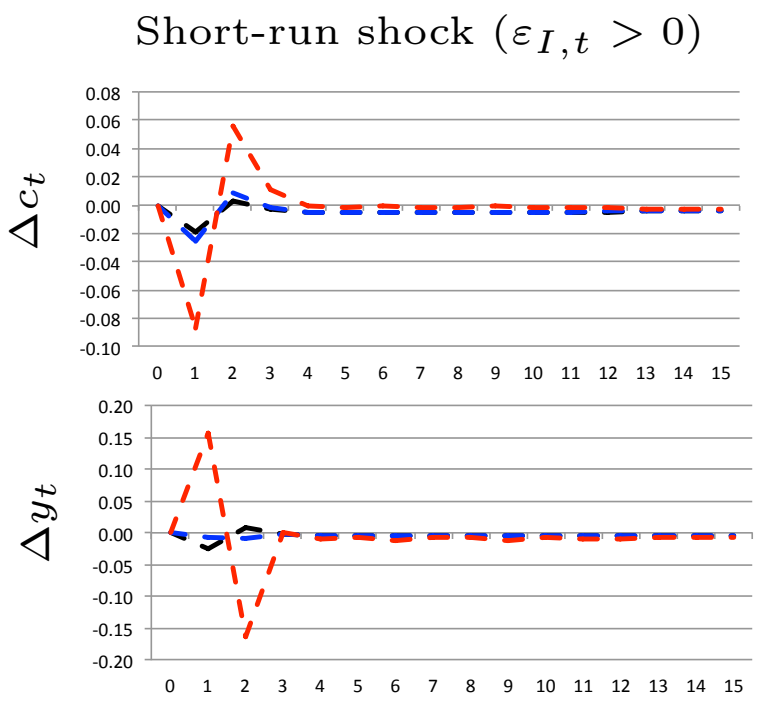

Long-run shock $\left(\varepsilon_{x, I, t}>0\right)$
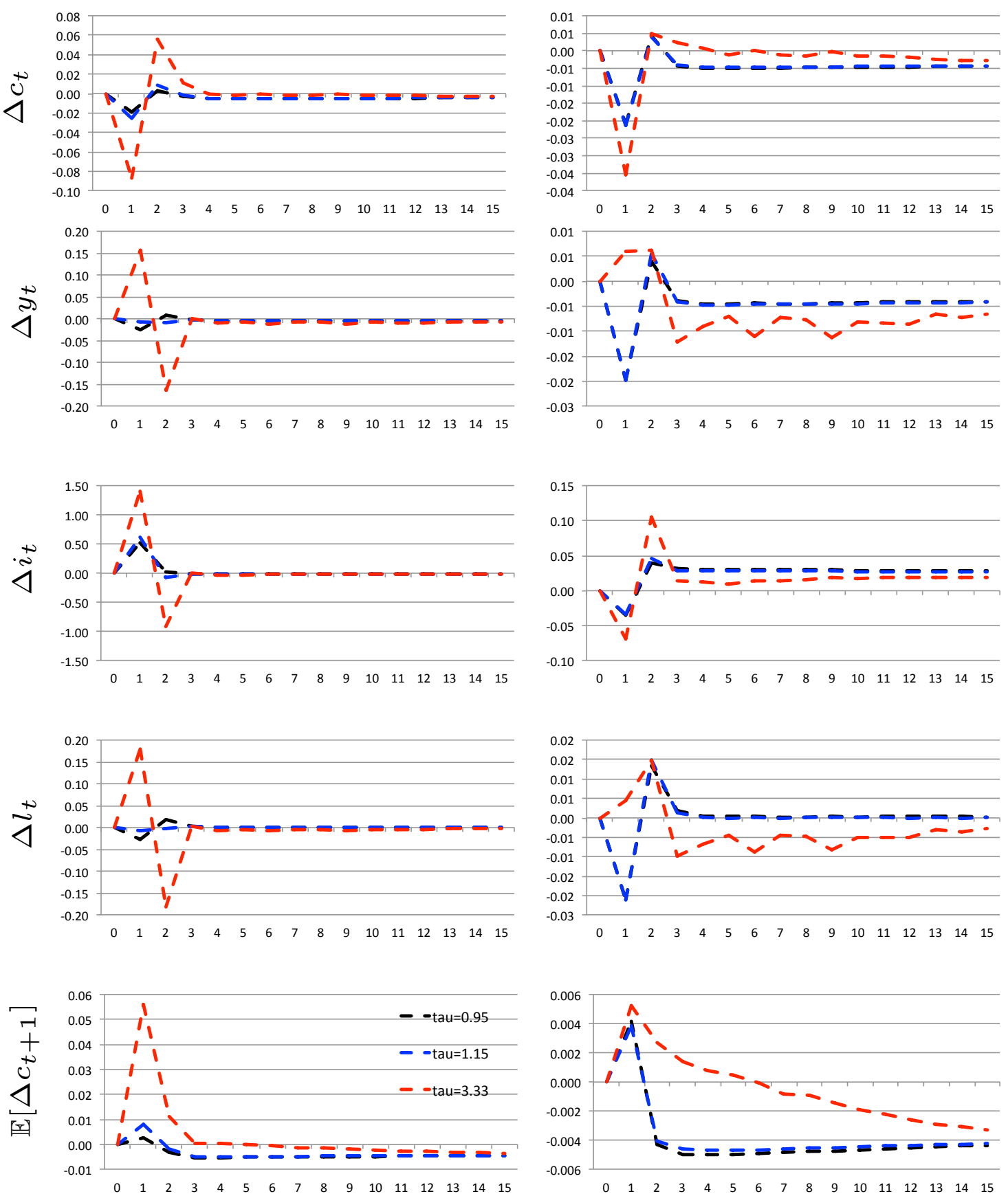

Notes: This figure depicts the impulse-response functions (expressed as deviations from the steady state in percentage points) for a length of 15 months of $\log$ consumption growth $\Delta c_{t}, \log$ output growth $\Delta y_{t}, \log$ investment growth $\Delta i_{t}$, log labor growth $\Delta l_{t}$, and expected log consumption growth $\mathbb{E}_{t}\left[\Delta c_{t+1}\right]$. Impulse-response functions with respect to a positive one-standard-deviation short-run shock to investment sector TFP $\varepsilon_{I, t}$ and to a positive one-standard-deviation long-run shock to investment sector TFP $\varepsilon_{x, I, t}$ are depicted. Moreover, three different elasticities of capital adjustment $\operatorname{costs}(\tau=0.95, \tau=1.15$, and $\tau=3.33)$ are used. The values reported are deviations from the steady state in percentage points. 
Figure C.3: Shocks to the MARginal EFFicienCy of InVESTMEnT
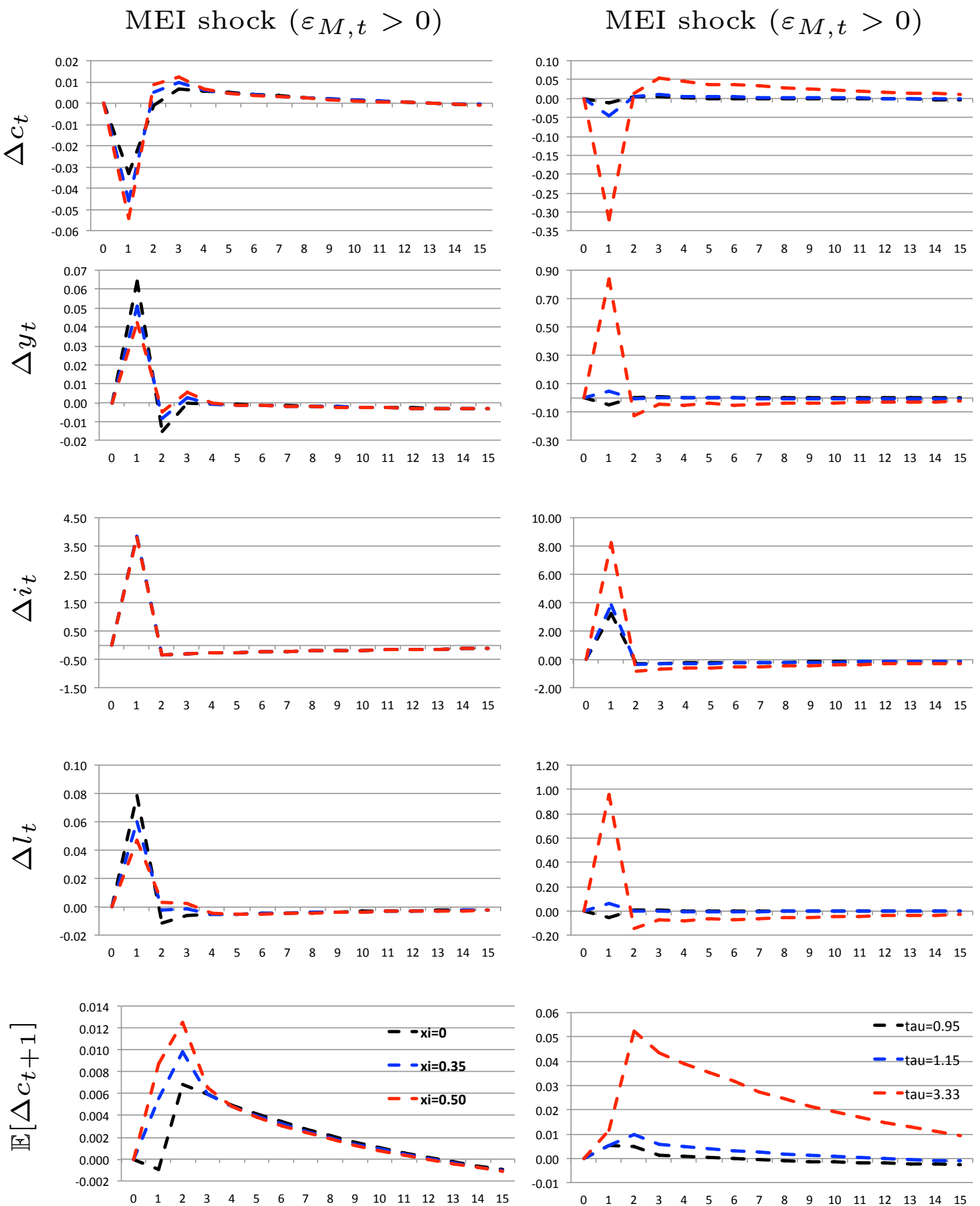

Notes: This figure depicts the impulse-response functions for a length of 15 months of log consumption growth $\Delta c_{t}$, $\log$ output growth $\Delta y_{t}, \log$ investment growth $\Delta i_{t}, \log$ labor growth $\Delta l_{t}$, and expected $\log$ consumption growth $\mathbb{E}_{t}\left[\Delta c_{t+1}\right]$. Impulse-response functions with respect to a positive one-standard-deviation short-run shock to the marginal efficiency of investment $\varepsilon_{M, t}$ are depicted. Moreover, in the left column three different degrees of wage rigidities $(\xi=0, \xi=0.35$, and $\xi=0.5)$ are used. In the right column three different elasticities of capital adjustment $\operatorname{costs}(\tau=0.95, \tau=1.15$, and $\tau=3.33)$ are used. The values reported are deviations from the steady state in percentage points. 


\section{C.2 Consumption sector TFP shocks}

Figure C.4: Consumption Sector shocks: The role of Wage Rigidities

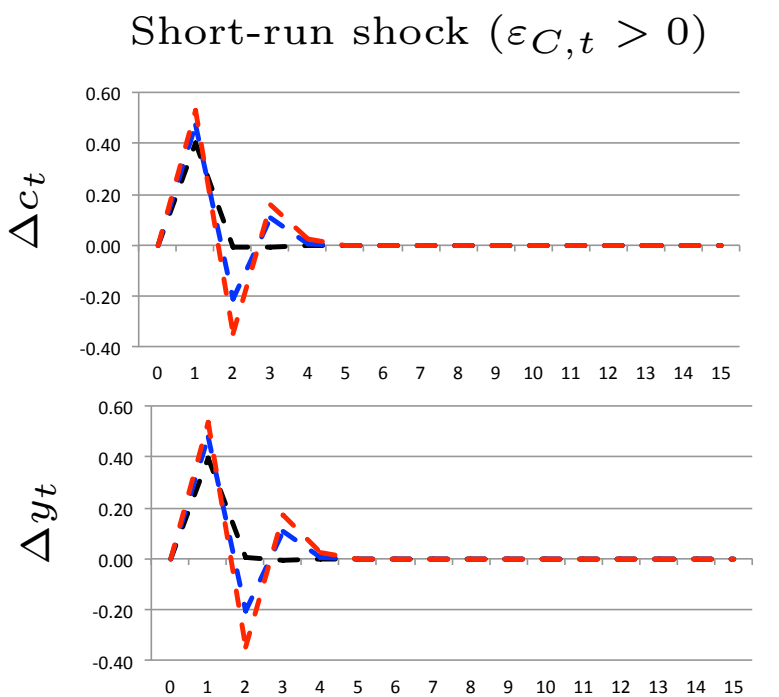

Long-run shock $\left(\varepsilon_{x, C, t}>0\right)$
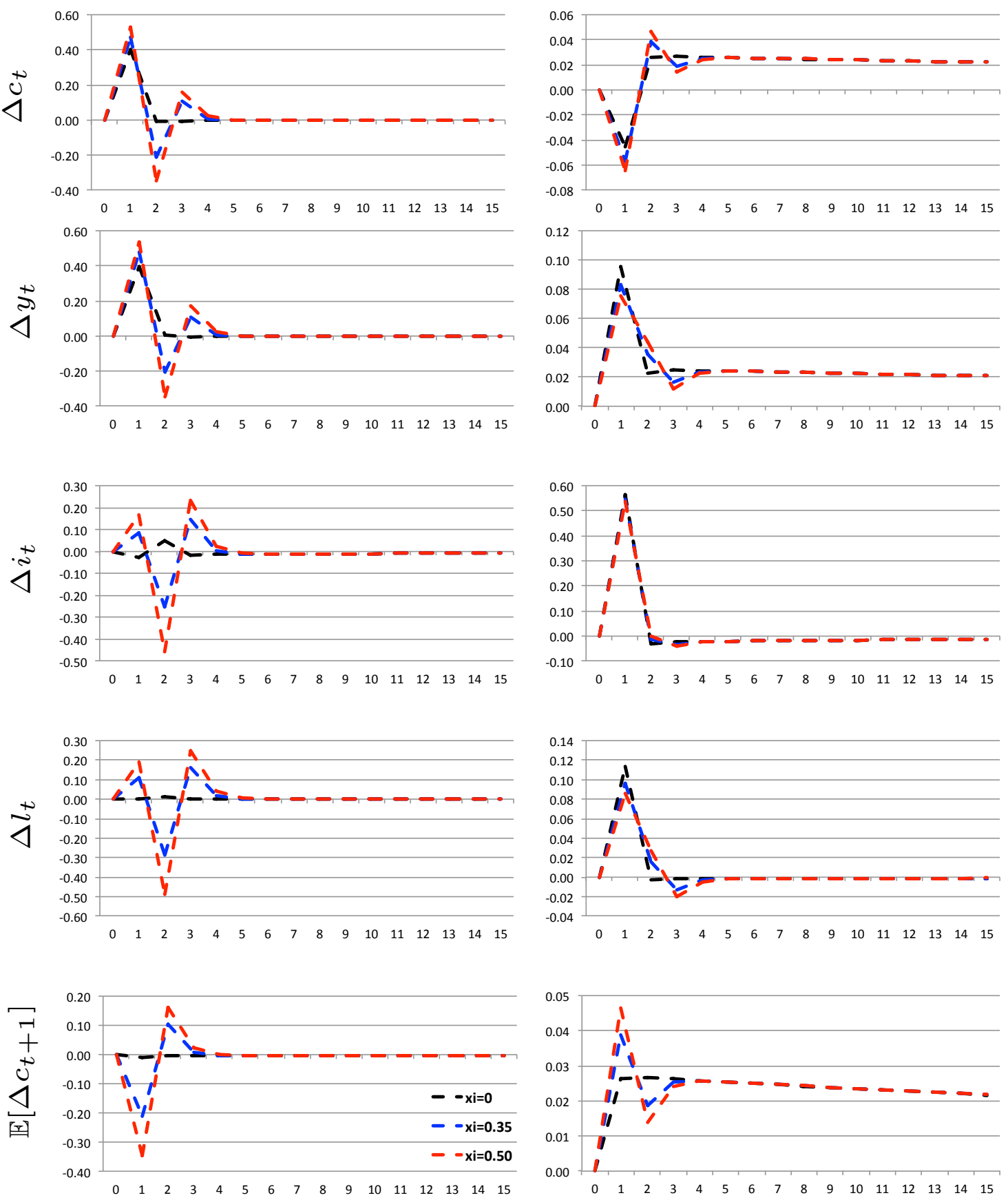

Notes: This figure depicts the impulse-response functions for a length of 15 months of log consumption growth $\Delta c_{t}$, $\log$ output growth $\Delta y_{t}, \log$ investment growth $\Delta i_{t}, \log$ labor growth $\Delta l_{t}$, and expected log consumption growth $\mathbb{E}_{t}\left[\Delta c_{t+1}\right]$. Impulse-response functions with respect to a positive one-standard-deviation short-run shock to consumption sector TFP $\varepsilon_{C, t}$ and to a positive one-standard-deviation long-run shock to consumption sector TFP $\varepsilon_{x, C, t}$ are depicted. Moreover, three different degrees of wage rigidities $(\xi=0, \xi=0.35$, and $\xi=0.5)$ are used. The values reported are deviations from the steady state in percentage points. 
Figure C.5: Consumption SeCtor shocks: The Role of Adjustment Costs

Short-run shock $\left(\varepsilon_{C, t}>0\right)$
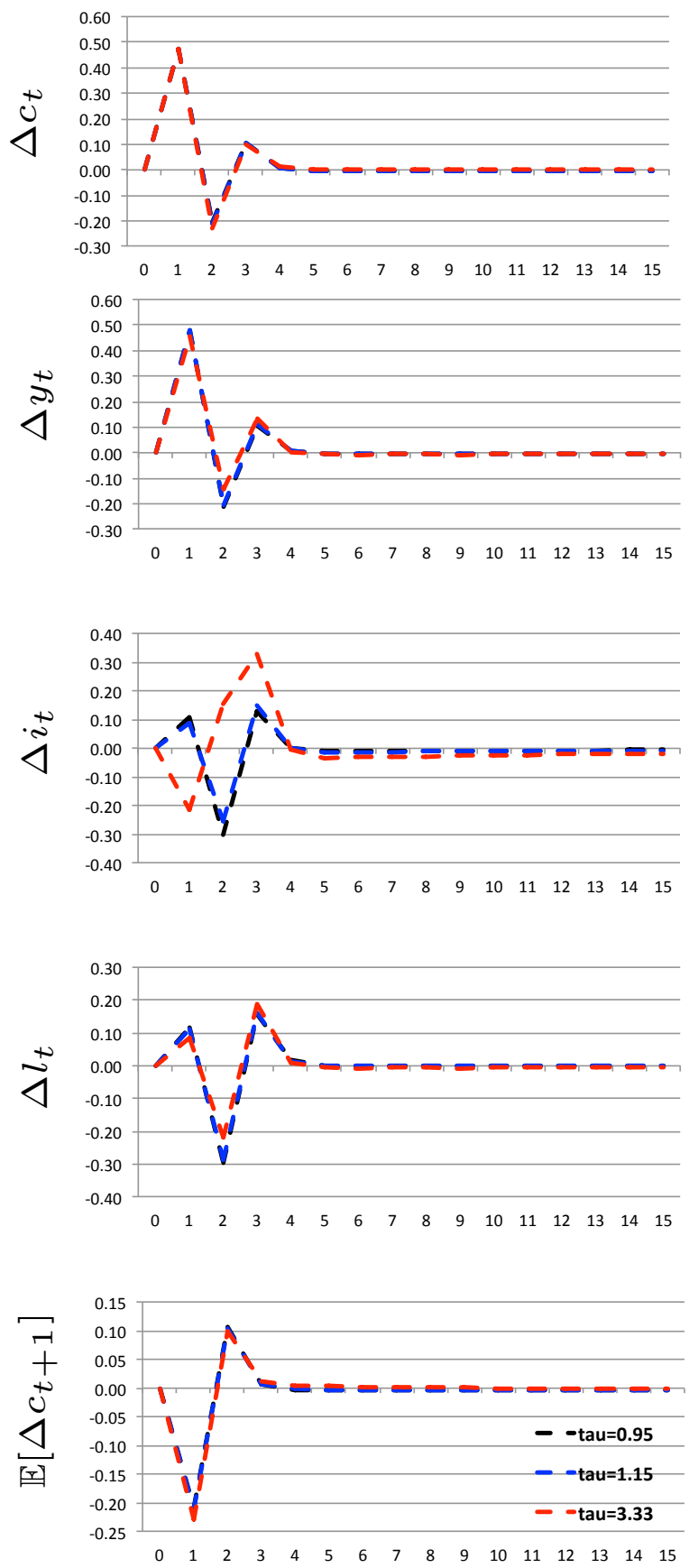

Long-run shock $\left(\varepsilon_{x, C, t}>0\right)$
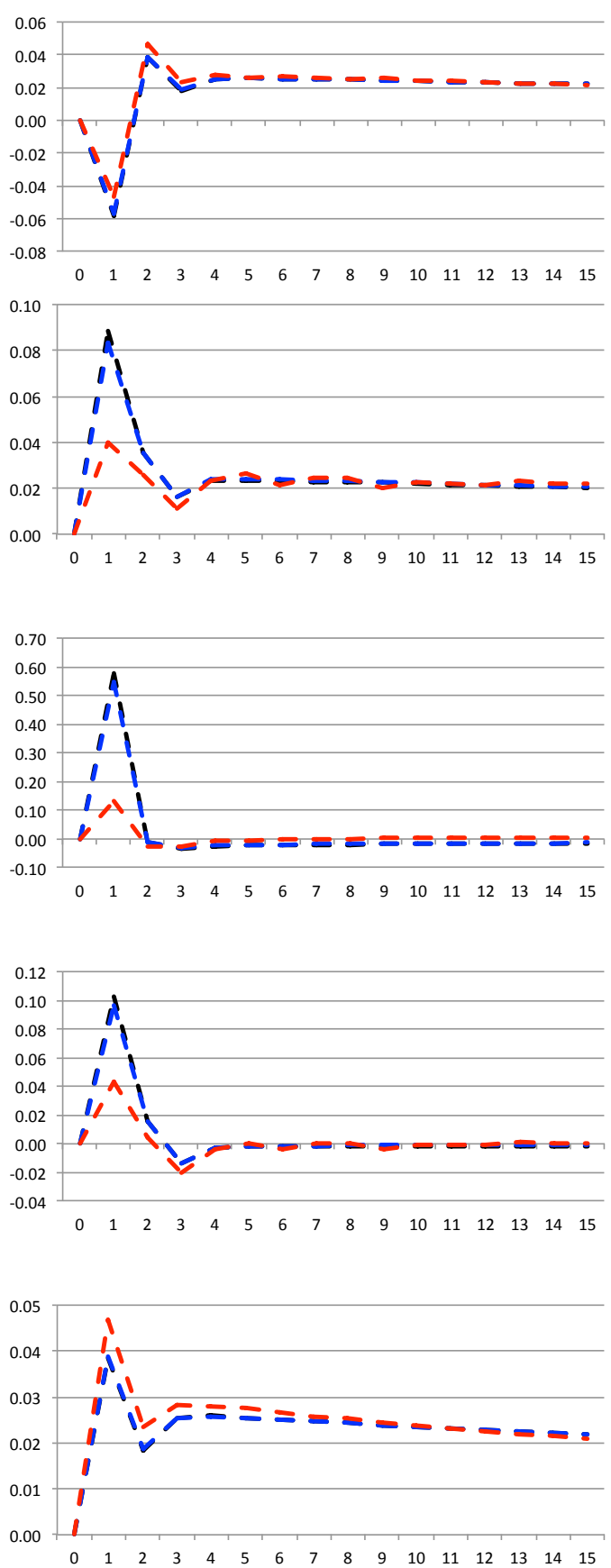

Notes: This figure depicts the impulse-response functions for a length of 15 months of log consumption growth $\Delta c_{t}$, $\log$ output growth $\Delta y_{t}, \log$ investment growth $\Delta i_{t}, \log$ labor growth $\Delta l_{t}$, and expected log consumption growth $\mathbb{E}_{t}\left[\Delta c_{t+1}\right]$. Impulse-response function with respect to a positive one-standard-deviation short-run shock to consumption sector TFP $\varepsilon_{C, t}$ and to a positive one-standard-deviation long-run shock to consumption sector TFP $\varepsilon_{x, C, t}$ are depicted. Moreover, three different elasticities of capital adjustment costs $(\tau=0.95, \tau=1.15$, and $\tau=3.33)$. The values reported are deviations from the steady state in percentage points. 


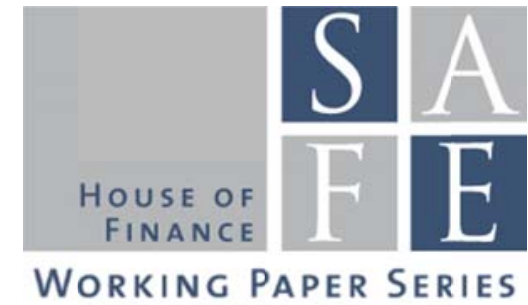

\section{Recent Issues}

No. 128 Giuliano Curatola

No. 127 Helmut Elsinger, Philipp SchmidtDengler, Christine Zulehner

No. 126 Carsten Bienz, Karin S. Thorburn, Uwe Walz

No. 125 Tobias H. Tröger, Uwe Walz

No. 124 Adrian Buss, Bernard Dumas, Raman Uppal, Grigory Vilkov

No.123 Marie Lalanne, Paul Seabright

No. 122 Douglas Cumming, Uwe Walz, Jochen Werth

No. 121 Elia Berdin, Matteo Sottocornola

No. 120 Matthias Heinz, Heiner Schumacher

No. 119 Michael Brennan, Holger Kraft

No. 118 Michael Donadelli, Antonio Paradiso, Max Riedel

No. 117 Marcel Bluhm

No. 116 Charles Gottlieb

No. 115 Andreas Fagereng, Charles Gottlieb, Luigi Guiso

No. 114 Nicole Branger, Christian Schlag, Lue $\mathrm{Wu}$
Preference Evolution and the Dynamics of Capital Markets

Competition in Treasury Auctions

Coinvestment and risk taking in private equity funds

Does Say on Pay Matter? Evidence from the German Natural Experiment

The Intended and Unintended Consequences of Financial-Market Regulations: A General Equilibrium Analysis

The Old Boy Network: The Impact of Professional Networks on Remuneration in Top Executive Jobs

The Dynamics of Entrepreneurial Careers in High-Tech Ventures: Experience, Education, and Exit

Insurance Activities and Systemic Risk

Signaling Cooperation

Leaning Against the Wind: Debt Financing in the Face of Adversity

A Ouasi Real-Time Leading Indicator for the EU Industrial Production

Interbank Funding as Insurance Mechanism for (Persistent) Liquidity Shocks

On the Distributive Effects of Inflation

Asset Market Participation and Portfolio Choice over the Life-Cycle

'Nobody is Perfect': Asset Pricing and Long-Run Survival When Heterogeneous Investors Exhibit Different Kinds of Filtering Errors 